\title{
Investigation of groundwater salinity using geophysical and geochemical approaches: heuningnes catchment coastal aquifer. Western Cape Province, South Africa
}

\author{
Portia Mokoena $^{1} \mathbb{D} \cdot$ Kinsley Manyama $^{1} \cdot$ Jan van Bever Donker $^{1} \mathbb{D} \cdot$ Thokozani Kanyerere $^{1}$ (D)
}

Received: 26 May 2020 / Accepted: 14 February 2021 / Published online: 27 February 2021

(c) The Author(s), under exclusive licence to Springer-Verlag GmbH, DE part of Springer Nature 2021

\begin{abstract}
Seawater intrusion is recognised as a major factor affecting the quality of groundwater in coastal aquifers around the world. To determine the occurrence and extent of saline groundwater intrusion prevailing in the Heuningnes Catchment, a 2D resistivity imaging survey was carried out in three sites within the catchment. Eleven resistivity profile lines were conducted using the multi-electrode ABEM SAS resistivity meter system, employing the Wenner Array to map the extent of saline groundwater. A 2D resistivity image was acquired for these resistivity profile lines and the data were processed using Res2DINV software to produce the $2 \mathrm{D}$ inverse resistivity models. The interpretation of the resistivity models revealed three resistivity zones. The first zone is characterised by low resistivity (1-3 $\Omega . \mathrm{m})$; this represents an aquifer filled with saline water. The second resistivity zone has values ranging from (3-30 $\Omega . \mathrm{m})$; this represents a brackish saturated formation. The third resistivity zone denotes a sandy layer/sandstone saturated with freshwater having high resistivity values above $30 \Omega . m$. Geochemical analysis results of water samples at 11 locations along the electrical resistivity profile lines also suggest high salinity, indicated by high levels of $\mathrm{Cl}^{-}, \mathrm{Na}^{+}$, Total Dissolved Solids, and Electrical Conductivity. It is concluded that some parts of the study area are impacted by seawater intrusion, based on the lower resistivity of $<3 \Omega$.m and ionic ratios which were close to the standard seawater ratios for $\mathrm{Na}^{+} / \mathrm{Cl}^{-}$and $\mathrm{SO}_{4}{ }^{2-} / \mathrm{Cl}^{-}$. In addition, the high ionic ratios of $\mathrm{Na}^{+} / \mathrm{Cl}^{-}$and $\mathrm{SO}_{4}{ }^{2-} / \mathrm{Cl}^{-}$suggest that salinity in the area is a result of dissolution of evaporates and dilution of marine clays rich in sodium. Therefore, salinization in the study area is the result of combined processes. Integration approach proved to be significant in mapping saline groundwater in coastal aquifers. Integrated assessment of resistivity data, ionic analysis and chemical interpretation indicate that the study area is a transition zone from freshwater to saltwater and only few locations are actually impacted by seawater intrusion. The overall groundwater quality is not apt for human ingestion.
\end{abstract}

Keywords Coastal aquifers $\cdot$ Electrical resistivity $\cdot$ Saline groundwater $\cdot$ Geochemistry

\section{Introduction}

Saline intrusion in coastal aquifers has become the main concern in the pollution of freshwater resources (Adepelumi et al. 2009). Understanding the origin and movement of saline intrusion is necessary for management of coastal groundwater resources. The management of groundwater in coastal areas across the globe is already in a critical state because urbanization and irrigated agriculture have claimed

Portia Mokoena

mokoena53@gmail.com

1 Department of Earth Sciences, University of the Western Cape, Private Bag X17, Bellville 7535, South Africa significant amounts of groundwater resources (Lewis et al. 2004; Gaaloul et al. 2012). Other threats to groundwater resources include domestic, agricultural and industrial effluents, brackish paleo-water (Song et al. 2006) failed wellcasings, saline water entrapped in clay layers and connate saline water from poorly flushed aquifers. Among these sources seawater intrusion is the utmost threat to the quality of groundwater in coastal aquifers, which has already resulted in a high desertion of water-wells in numerous regions (Lagudu et al. 2013; Felisa et al. 2013).

The invasion and encroachment of saline water from oceans to freshwater aquifers in coastal regions is well known. The continued overexploitation of groundwater in coastal areas results in lowering the water table in coastal aquifers. Under normal conditions the hydrogeological 
gradient should be from land towards the ocean (Hodlur et al. 2010). However, due to the overexploitation this has now been upturned from ocean to inland, which expedites the process of saline water intrusion. Commonly, seawater intrusion through an aquifer is assessed through the installation of observation-wells and chemical studies on the water they produce (Song et al. 2006). However, Ravindran et al. (2013) state that it is not easy to install monitoring-wells without the knowledge on the extent of seawater intrusion, because the lateral resolution is often limited by well spacing. Geophysical methods using either electrical resistivity or electromagnetic survey avoid the need for drilling to locate seawater wedges and are highly effective in monitoring saltwater intrusion (Hamdan et al. 2010). These methods also provide complementary data that permit geological correlation, even in areas where there are no data from boreholes. The spatial relations between fresh, brackish, and saline water, which normally coexist in coastal aquifers can be easily comprehended through geophysics methods (Supriyadi and Putro 2017). The capability to discriminate large resistivity contrast between the presence of seawater that strongly reduces the resistivity values and saturated freshwater layers (Mogren 2015) made this geophysics technique to be the most preferred especially for seawater intrusionrelated investigations in coastal aquifers. Various studies have used this method coupling it with geochemical analysis to investigate seawater intrusion in coastal aquifers (Rao et al. 2011; Lagudu et al. 2013) while other authors used it to map saline groundwater in coastal areas (Kelly 2011; Macquarrie et al. 2012). Adepelumi et al. (2009) highlighted the effectiveness of DC resistivity method in demarcating the saline water freshwater interfaces, while establishing suitable areas for groundwater development in Nigeria. Oyeyemi et al. (2015) used geophysical and geochemical investigations to demarcate probable saltwater intrusion in coastal alluvial aquifers, map the extent of groundwater contamination, and evaluate the groundwater quality in coastal aquifers of Lagos. The application of geophysical methods in conjunction with chemical data for evaluating seawater intrusion in coastal aquifers is well-documented worldwide.

However, the application of such approach is not common in the studied region. There are no records of seawater intrusion studies in the region and such studies are scarce in South Africa in general. This study is the first attempt to evaluate seawater intrusion using multi-approach. Previous hydrogeological investigation by (Toens et al. 1998) was conducted for locating and developing groundwater resources to meet the increasing demand of water supply in the area. Groundwater in the region is being accessed through drilled boreholes, hand-dug wells and regional springs. The water use is mainly for drinking, small-scale irrigation and livestock watering. A major challenge in the Heuningnes Catchment is that salinity of groundwater is very high to a point where it was declared unsuitable for domestic use or irrigation in certain parts of the catchment. The salinity levels reported, based on Electrical Conductivity (EC), range from 5000 to $10,000 \mu \mathrm{S} / \mathrm{cm}$ (Toens et al. 1998); therefore, the knowledge of the spatial distribution of fresh and saline groundwater and the processes governing salinity within the aquifer system, is essential for proper planning of available potable groundwater resources. The high salinity recorded in the study-area has compelled this study to evaluate the significance of integrated datasets from geophysical technique and chemical method in understanding the origin of salinity within the aquifer whether it is a result of seawater impact or there are other hydrochemical processes at play. The status of groundwater quality for drinking purposes in the Heuningnes Catchment is assessed as well.

\section{Study location}

The study site is located in Eastern Overberg in the Western Cape Province, South Africa (Fig. 1). The Heuningnes Catchment ( $\left.34^{\circ} 42^{\prime} 50^{\prime \prime} \mathrm{S} ; 20^{\circ} 07^{\prime} 13^{\prime \prime} \mathrm{E}\right)$ lies $160 \mathrm{kms}$ southeast of Cape Town and $35 \mathrm{kms}$ north of Cape Agulhas. The main rivers feeding the catchment include Kars, Heuningnes, and Nuwejaars rivers. The catchment occupies a total area of about $1400 \mathrm{~km}^{2}$ and contains Bredasdorp, Elim and Napier as the major towns. About $56 \%$ of land coverage is natural vegetation consisting mainly of shrubland, grassland, bushland, wetland and water bodies (Herdien et al. 2005). The main water bodies include Soetendalsvlei followed by Voëlvlei and some small pans. Wetlands may also indicate a recharge zone for groundwater depending on their topographic position. About $41 \%$ of the catchment is agricultural land, primarily used for provisional dry agriculture and improved grassland (Herdien et al. 2005). Small-scale irrigation accounts for $1.1 \%$ on cultivated area for orchards and vineyards. The study site experiences a Mediterranean climate with wet cold winters and dry hot summers. Over $50 \%$ of annual rainfall occurs between April and August and the Mean Annual Precipitation is about $400 \mathrm{~mm}$. The study site is dominated by calcareous sands, coarse sands, alluvial top soils, clays, acidic and highly leached soils. Peat layers are also visible in some areas and often occur between the top sandy layer and clay layer (Russell and Impson 2006).

\section{Geological setting}

Geologically sedimentary rocks overlaying the crystalline rocks of the Malmesbury slates dominate the study site. The study site is locally confined within the Table Mountain and the Bokkeveld Groups of the Cape Supergroup that was 


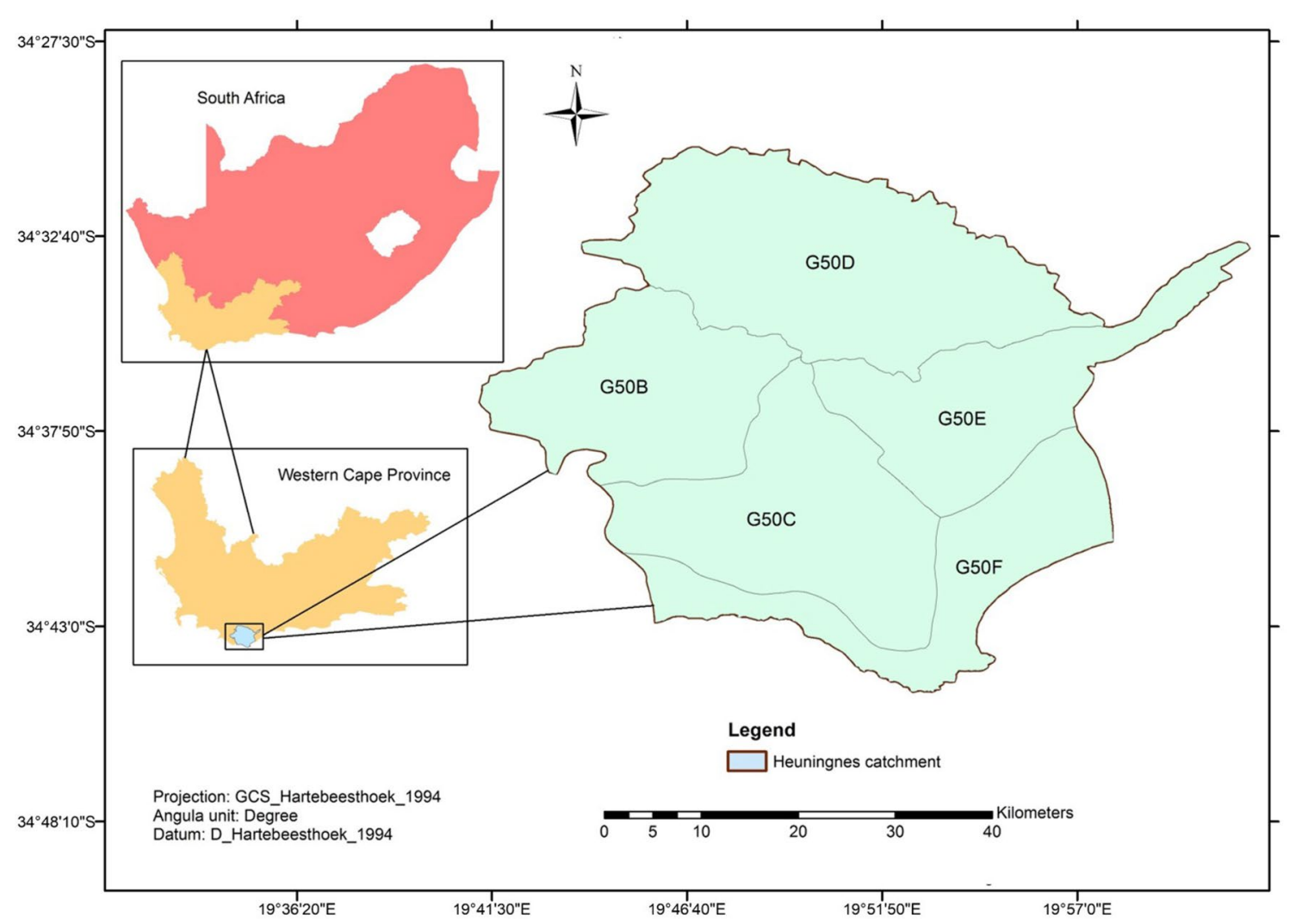

Fig. 1 Map of the study site Heuningnes Catchment

deposited early Ordovician ( $500 \mathrm{Ma})$ to the early Carboniferous ( $330 \mathrm{Ma})$. The succession of sandstones, shales and conglomerates of the Table Mountain and Bokkeveld Groups overlies the Malmesbury Group (Fig. 2). The Malmesbury Group consists of low grade metamorphic rocks, such as phyllitic shale, quartz, and sericitic schist, siltstone, sandstone and greywacke (Meyer 2001). The Malmesbury Group is intruded by the granite plutons of the Cape Granite Suite. The Table Mountain Group (TMG) is of Palaeozoic age, and is overlain by the Bokkeveld Group (Fig. 2). The TMG is dominated by quartzitic sandstones, shales, siltstones and some conglomerates. This group (TMG) was affected by deformation, which resulted in the formation of faults, folds and joints in the Quartzitic sandstones in the area, the fractured aquifer is a perfect host for groundwater (Xu et al. 2009). The Bokkeveld Group overlies the TMG and is of Devonian age made up of an alteration of fine-grained sandstones and mudrock units. These deposits dominate towards the eastern side of the catchment between Elim and the lake called Soetendalsvlei.

The Bokkeveld formation is sandwiched between the TMG and the Bredasdorp group (Mazvimavi 2018) where it consists of shales and thin interbedded sandstones derived from marine continental slope muds. Lastly, the Bredasdorp Group which is a quaternary deposit, covers the older rocks of the Bokkeveld Group and the TMG. This group consists of calcified dune sands and coastal limestone beds which mostly outcrop between Soetendalsvlei and the Heuningnes estuary.

The geological setting of an area influences the movement, quality, occurrence and availability of groundwater resources (Rajaveni et al. 2017). Groundwater bearing formations in the study region are mostly the fractured quartzitic sandstone of the TMG, shales of the Bokkeveld group and the quaternary deposits (Mokoena et al. 2020). Groundwater associated with the TMG is of good quality but requires treatment because of its high iron content. This is in contrast to the groundwater associated with the shale and limestone of the Bokkeveld Group, which is mostly alkaline and in some cases brackish, making it unsuitable for human consumption.

\section{Materials and methods}

\section{Geophysical investigation}

The $2 \mathrm{D}$ electrical resistivity imaging is a surveying technique that is used to attain in depth subsurface information especially in regions with complex geology or with 


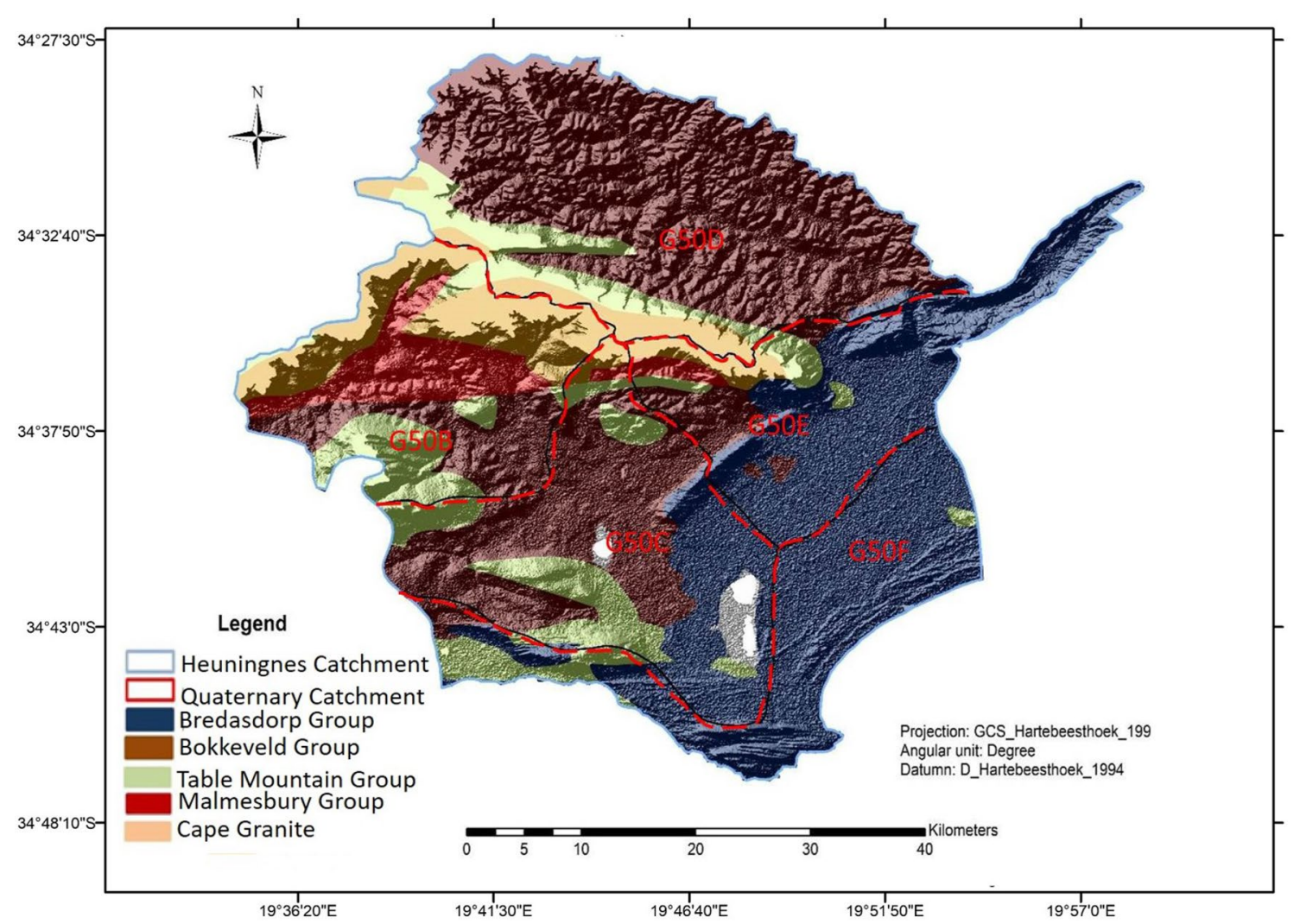

Fig. 2 Geological setting of the study site (Mokoena et al. 2020)

restricted surface outcrops where other techniques are unfit to provide subsurface data (Dushiyanthan et al. 2014). During an electrical resistivity survey, an electrical current is introduced into the ground by means of metal electrodes to detect the electrical resistivity deviation in the subsurface formation (Fig. 3).

The Electrical Resistivity Imagery (ERI) data were collected in September and October 2014 at three sites (Soetendalsvlei, Voëlvlei and Elandsdrift) in the Heuningnes Catchment study area. The data acquisition was collected in different months due to land access issues. The location of the ERI profile lines are shown in the red text in Fig. 4. An ABEM Terrameter-SAS 1000 resistivity meter with a multi-electrode switch system in a roll-along Wenner Array configuration with 64 channels was used for the survey. A roll-along method is useful in extending the horizontal area during a survey especially for a system with a restricted number of electrodes (Hazreek et al. 2018). Electrodes were connected through multicore cables to a switch panel placed at the middle of the profiling (Fig. 3). The currentand potential-terminals from the switching panel were connected to the corresponding terminals of the Terrameter. Upon completion of measurements, the cable is shift past one end of the line by couple of units of electrode spacing. Electrode spacing along a survey line is important for the examination of lateral variation in earth resistivity. For instance, larger electrode spacing in an array gains more depth of penetration, and a smaller electrode spacing gains more resolution (Lagudu et al. 2013). In this study, the electrodes were planted in the ground at about $30 \mathrm{~cm}$ deep with electrode spacing of $4 \mathrm{~m}$, which acquired an investigation depth of $25 \mathrm{~m}$. This array was chosen because of its high

Fig. 3 General resistivity set-up and the final 2D image processed by 2D inversion (Yusof et al. 2016)

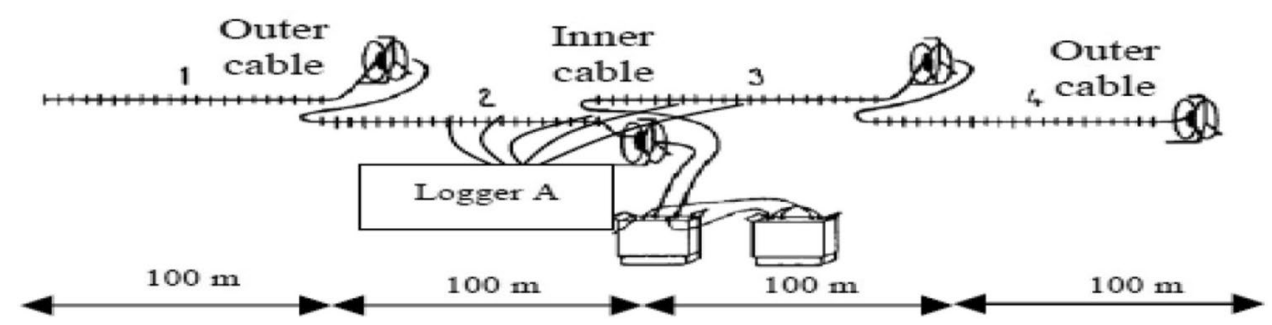




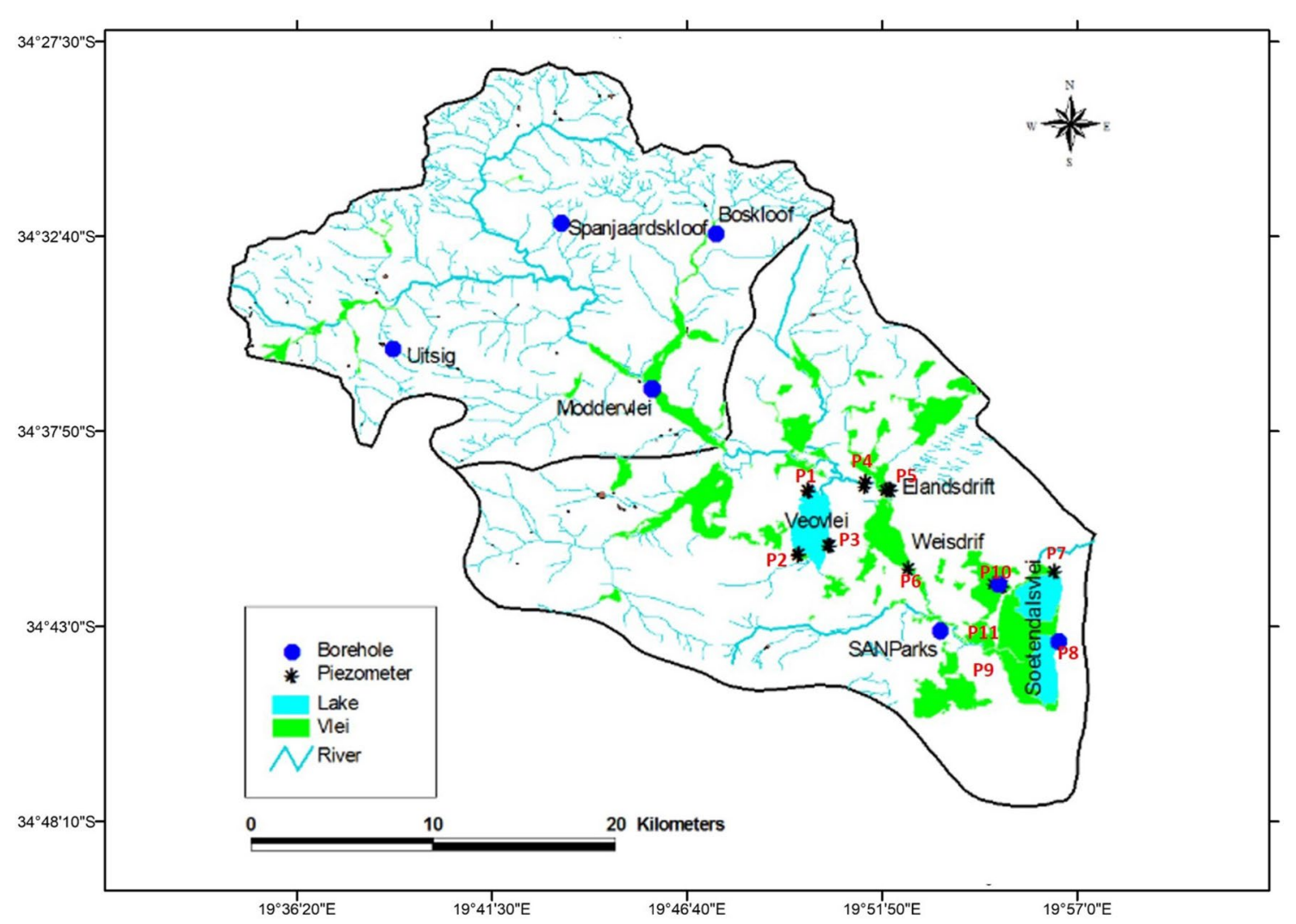

Fig. 4 Map showing resistivity profile lines at Heuningnes Catchment presented by the red text (Modified after Mazvimavi 2018)

signal strength and the ability to give good vertical resolution. This is an advantageous factor in areas with a lot of background noise. The input current varied from 20 to 200 milli-amperes.

A software inversion algorithm (RES2DINV) was used to process the measured resistivity data to produce a $2 \mathrm{D}$-resistivity model (Hazreek et al. 2018). The inversion routine used by the RES2DINV programme is based on a smoothness-constrained least square inversion algorithm. The programme performs this task by dividing the subsurface into rectangular blocks (Loke 1999). The apparent resistivity was calculated in accordance with the finite- difference methods. Then the pseudosection contouring method was used to display apparent resistivity values. To reduce the difference between the measured apparent resistivity values and calculated resistivity values to the nearest minimum, the resistivity of the block was adjusted iteratively (OhwoghereAsuma et al. 2014). The magnitude of the difference was measured by Root Mean-Squared error (RMS).

\section{Geochemical investigation}

Eleven groundwater samples were collected at different water sampling points, two from boreholes $(\mathrm{BH})$ and nine from piezometers (PZ) to achieve chemical assessment. Field measurements of Electrical Conductivity (EC), Total Dissolved Solids (TDS), and $\mathrm{pH}$ of groundwater were measured onsite using an YSI Professional Plus 20 ${ }^{\mathrm{TM}}$ Multi-parameter sonde. The samples were analysed for major cations (Sodium $\left(\mathrm{Na}^{+}\right)$, Calcium $\left(\mathrm{Ca}^{2+}\right)$, Magnesium $\left(\mathrm{Mg}^{2+}\right)$, and Potassium $\left(\mathrm{K}^{+}\right)$) and major anions $\left(\right.$Chloride $\left(\mathrm{Cl}^{-}\right)$, Bicarbonate $\left(\mathrm{HCO}_{3}{ }^{-}\right)$, and Sulphate $\left.\left(\mathrm{SO}_{4}{ }^{2-}\right)\right)$ at Bemlabs. Prior to sample collection, field variables would first be monitored until they stabilized, indicating equilibrium in the instrument measurements. When these parameters had stabilized, a sample was collected and stored in polyethylene bottles $(250 \mathrm{ml})$ that had been pre-rinsed with dilute sulfuric acid (to $\mathrm{pH}$ 2.0) for chemical analysis. Samples were kept on ice during transportation to the laboratory to preserve the integrity of the sample contents.

The collection of groundwater samples for chemical analysis along with the measurement of field parameters for water quality was done in accordance to standard sampling procedure suggested by (Weight 2008). All analyses were concluded according to ISO/IEC 17,025 standards, and the testing laboratories are South African National Accreditation System (SANAS) accredited. Samples were prepared using SANS accredited methodology (SANS 11,885:2008). Cation analysis was done with Inductive Coupled Plasma Optic Emission Spectroscopy, while anions were analysed 
using Ion Chromatography. The uncertainty of measurements for all elements analysed ranged between $0.000 \%$ and $8.55 \%$.

\section{Results and discussion}

\section{Geophysical investigation}

The subsurface can be easily characterised by interpreting the resistivity of different subsurface materials because resistivity varies with lithology (Bouderbala et al. 2016). Also, the ionic concentration and the amount of dissolved solids cause resistivity to vary (Adepelumi et al. 2009). For instance, sandy zones filled with air or fresh water generally have resistivity values of 30 to $50 \Omega \mathrm{m}$ or higher depending on the silt content of the sand. Whereas, clay rich soils have resistivity values of about 20 to $30 \Omega$ m or less. Sandy zones filled with brackish or saline water have low resistivity values, typically 1 to $10 \Omega \mathrm{m}$ or less, depending on the degree of salinity in the groundwater (Johnson et al. 2008; Bouderbala et al. 2016). The resistivity values of different materials encountered in the study region are tabulated in Table 1. The resistivity models for all three sites are in Figs. 5 and 6.

Eleven Resistivity Imaging (ERI) profiles were conducted at three sites (Voëlvlei, Elands-drift and Soetendalsvlei) within the Heuningnes Catchment. Only ten of the profiles are presented here, the 11 th profile is similar to Profile 9 (P9) therefore, it can be interpreted in unison. The names of the profile lines (Profile 1 to Profile 9) are referred to as P1 to P9. In all three sites, the ERI profiles exhibited resistivity values that differs laterally and at depth, and from this results significant information regarding the geology of the subsurface and fluid content was understood. The resistivity profiles depict four layers of resistivities: a saline water saturated layer ( $1 \Omega . \mathrm{m}-3 \Omega . \mathrm{m})$; a transition layer or rather

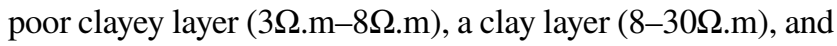
finally a layer of sandstone or shale $(56 \Omega . \mathrm{m}-111 \Omega . \mathrm{m})$. The low resistivity (1-3 $\Omega . \mathrm{m}$ ) layer reflects an aquifer containing material saturated with saline water. The inferred lithologies from the 2D resistivity models include from the surface alternating layers of sandy clays, clays, fine sands, loamy clay, sandstone and shales of various degree of weathering.

Resistivity profiles P1-3 were surveyed at Voelvlei site and the maximum horizontal distance for all three were
$224 \mathrm{~m}$ with $20 \mathrm{~m}$ depth. In $\mathrm{P} 1$ low resistivity layer $<3 \Omega \mathrm{m}$ dominates the left part of the profile while the right is dominated by high resistivity $(56.7-111 \Omega \mathrm{m})$ layer from $5 \mathrm{~m}$ depth (Fig. 5). In this profile, the distinction between saline saturated layers (blue) and freshwater saturated layer (purple) is apparent. In P1 (Fig. 5), the low resistivity layer intrudes the low permeability layer as shown by the green colour in the resistivity model. This is the suggested preferential flow path for the distribution of saline water into aquifers. Beneath this

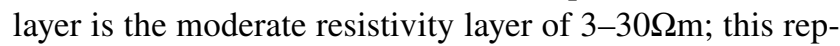
resents a more permeable material or clay-poor formation, filled with brackish groundwater. In P3 and P5 (Fig. 5), this layer is more dominant near the surface at a depth of less than $10 \mathrm{~m}$. The presence of fresher water compared to the saline water in part of the aquifer may indicate either fresh rainwater that was recently recharged, or recharged water from the lake to the shallow aquifer, whereas the fresher water at depth may be related to fresh water from a deeper aquifer. Lastly, the third layer is the high resistivity layer (over $30 \Omega . \mathrm{m}$ ) at $5 \mathrm{~m}$ from surface up to $25 \mathrm{~m}$ of depth. It should be noted that this depth is not constant as it varies from site to site. This layer represents fractured sandstone filled with either fresh water or air.

Some of the resistivity models such as P2, P4, P5 and P6, reveal a dominant trend of increasing resistivity with depth indicating decreasing salinity with depths. Whereas in P1, salinity increases horizontally with increasing distance indicating freshening of groundwater (Fig. 5). Resistivity profiles in Elandrift had maximum distance of $168 \mathrm{~m}$ and the depth of investigation was up to $25 \mathrm{~m}$. In Profile 4 in Elandsdrift, the top layer reveals low resistivity $1-3 \Omega \mathrm{m}$ from the surface up to a depth of $15 \mathrm{~m}$, this indicates a sandy clay formation saturated with saline water (Fig. 6). Beneath this layer is medium $3-14.8 \Omega \mathrm{m}$ resistivity indicating a fine sand layer with more brackish water; a similar layer is encountered in P5 and P6.

In the Soetendalsvlei, the models show variations of resistivity in the subsurface (Fig. 7). The resistivity layers reflected by these models corresponds with the local geology of the area suggesting that the near surface material comprises fine sandy to clayish material (P8 in Fig. 7), while the deeper materials vary from fine sand, sandstone of the Table Group Mountain to shale of the Bokkeveld Groups (P7 and 9 in Fig. 7). Weathering of these materials explains the change in high resistivity to lower resistivity, which is inferred as the
Table 1 Interpretation of resistivity value in the study site

\begin{tabular}{lll}
\hline Resistivity & Material & Indication \\
\hline$<3 \Omega . \mathrm{m}$ & Sand saturated with Saline water & Dark blue colour \\
$3-8 \Omega . \mathrm{m}$ & Clay/sand saturated with saline water & Light blue \\
$8-30 \Omega . \mathrm{m}$ & Clay layer with thin sand lenses (Brackish water) & Turquoise-green colour \\
$30-111 \Omega . \mathrm{m}$ & Sandstone saturated with fresh water or shale formation & Red to purple colour \\
\hline
\end{tabular}




\section{Southwest}

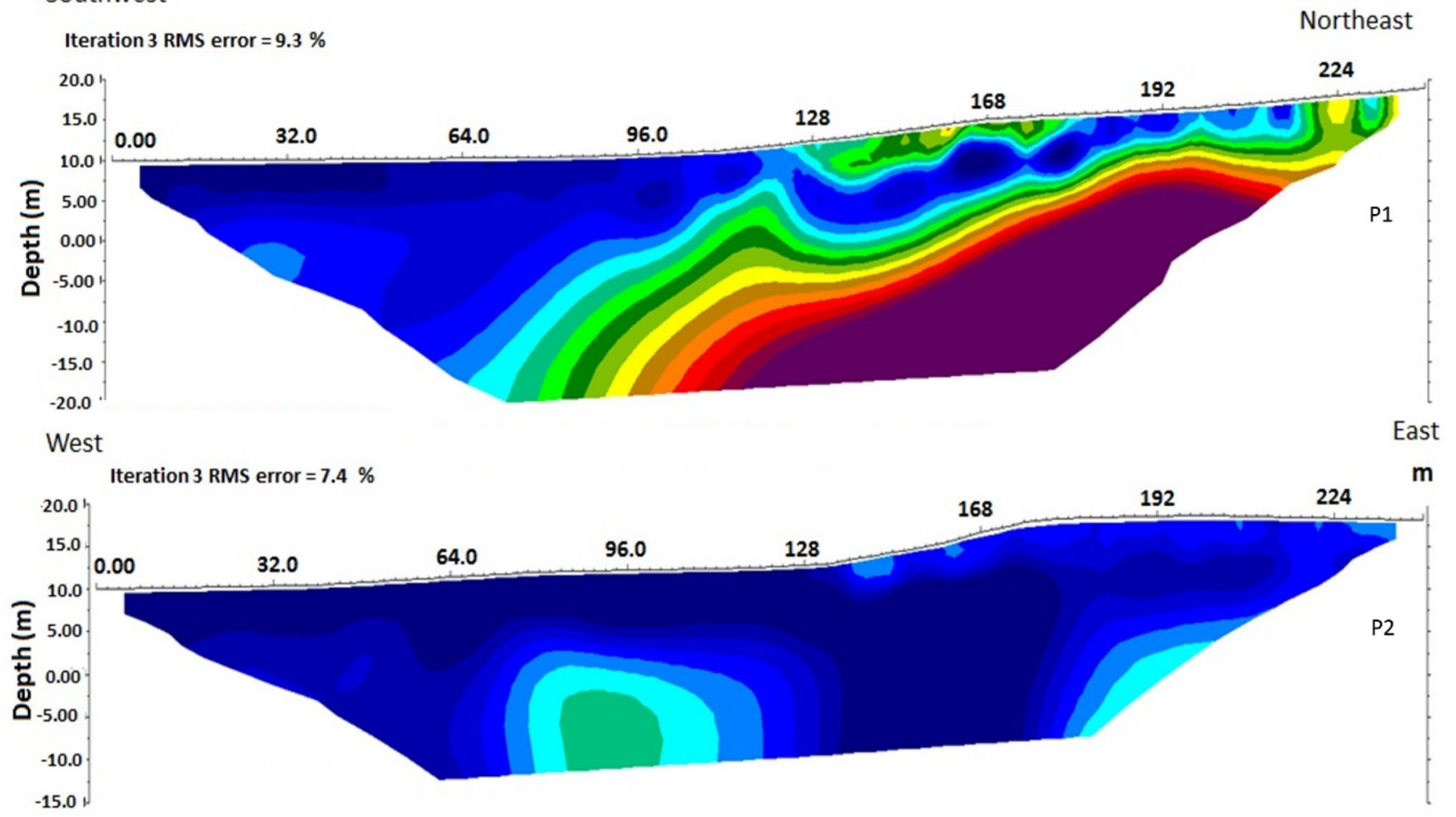

Southeast

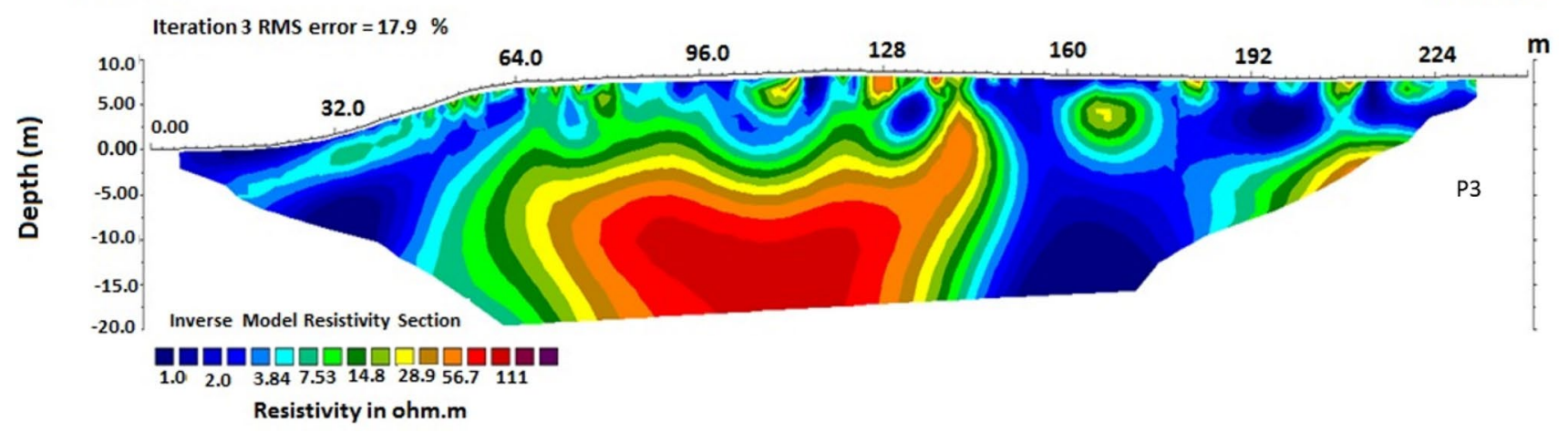

Fig. 5 Electrical Resistivity Imaging (ERI) profiles in Voëlvlei (P1-3) sites

transition zone in the resistivity models. Also, the transition zone serves as the boundary separating the aquifer containing saline water from the aquifer with fresh water (P1, P3, P7 and P9) in Figs. 5 and 7. Similar results were encountered in a study by Johnson et al. (2008), and the ERI was able to differentiate layers saturated with brackish and saline water at depths between 200 and 500 feet.

There is no standard interpretation or a fixed-universal value for seawater using ERI because it varies according to the geological setting of a particular area. Therefore, various studies have used different resistivity interpretations for seawater based on their own localisms. The resistivity of groundwater fluctuates from 10 to $100 \Omega \cdot \mathrm{m}$. depending on the concentration of dissolved salts (Loke 1999). A study by Vann et al. (2020) used a resistivity lower than $30 \Omega \mathrm{m}$ with TDS above $1500 \mathrm{mg} / \mathrm{l}$ as a threshold for the interpretation of seawater intrusion. A low resistivity zone below $10 \Omega \mathrm{m}$ is regarded as indicating the presence of seawater intrusion (Vann et al. 200). Whereas, in a study done by Hazreek et al. (2018) seawater was associated with resistivity values below $5 \Omega \mathrm{m}$, brackish water associated with resistivity value of $5-15 \Omega \mathrm{m}$ and lastly freshwater was considered to have resistivity of $50-100 \Omega \mathrm{m}$. Satriani et al. (2012) reported that seawater has an average of $0.2 \Omega \mathrm{m}$ whereas the resistivity of a layer saturated by saline water and dissolved solids is in the range of 8 to $50 \Omega \mathrm{m}$. Therefore, based on these values of resistivity of layers saturated by saline water and some dissolved solids 
Northeast

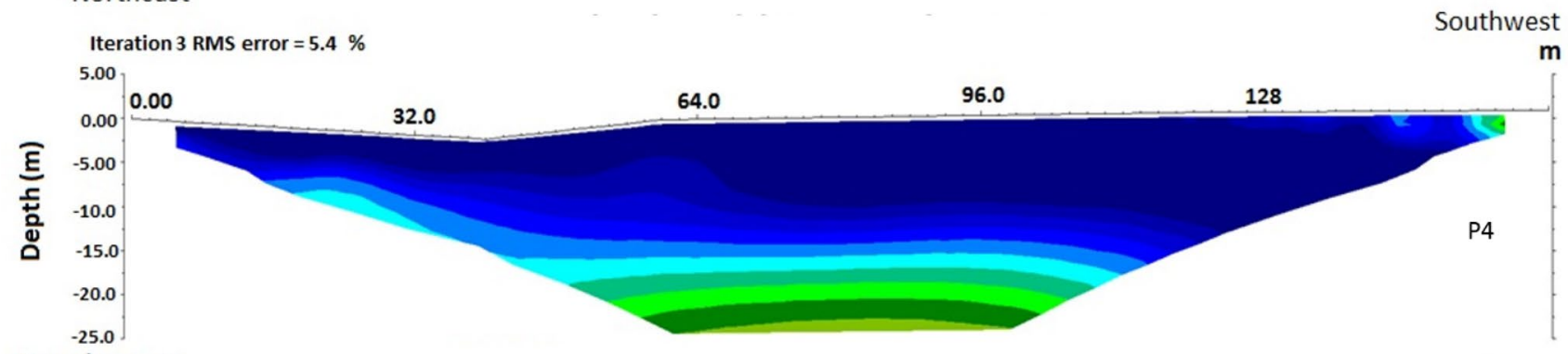

Southwest

Northeast

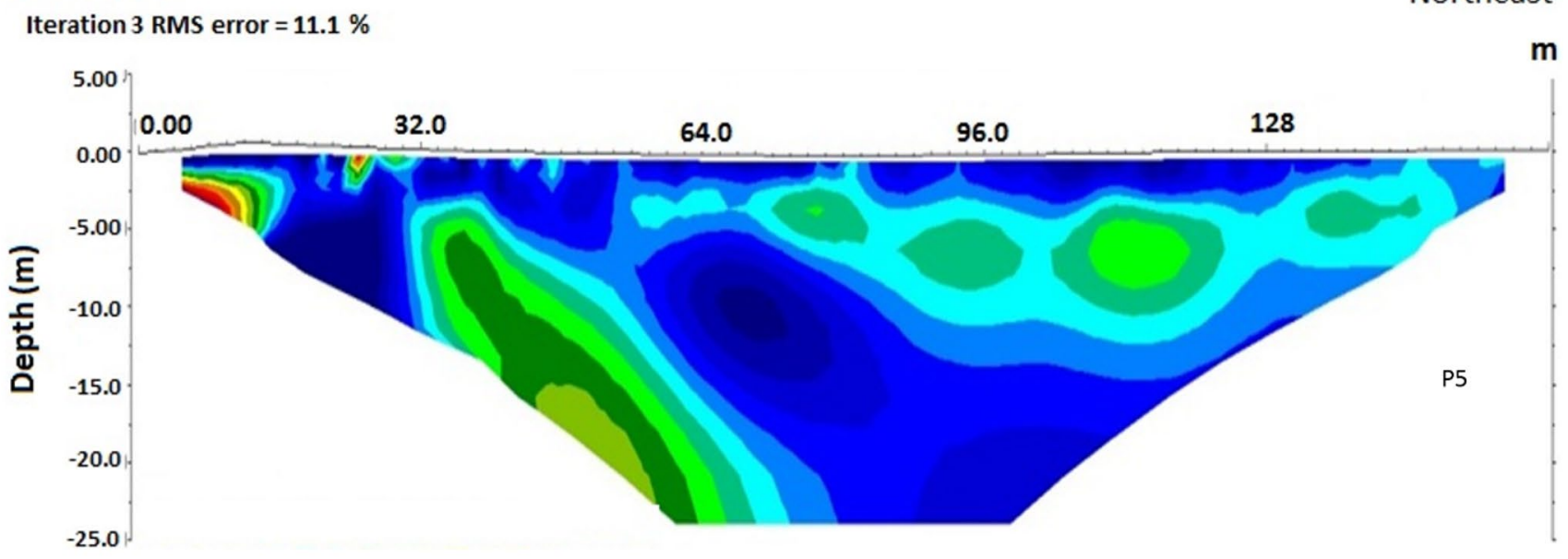

Southeast

Northwest

Iteration 3 RMS error $=\mathbf{1 4 . 6} \%$

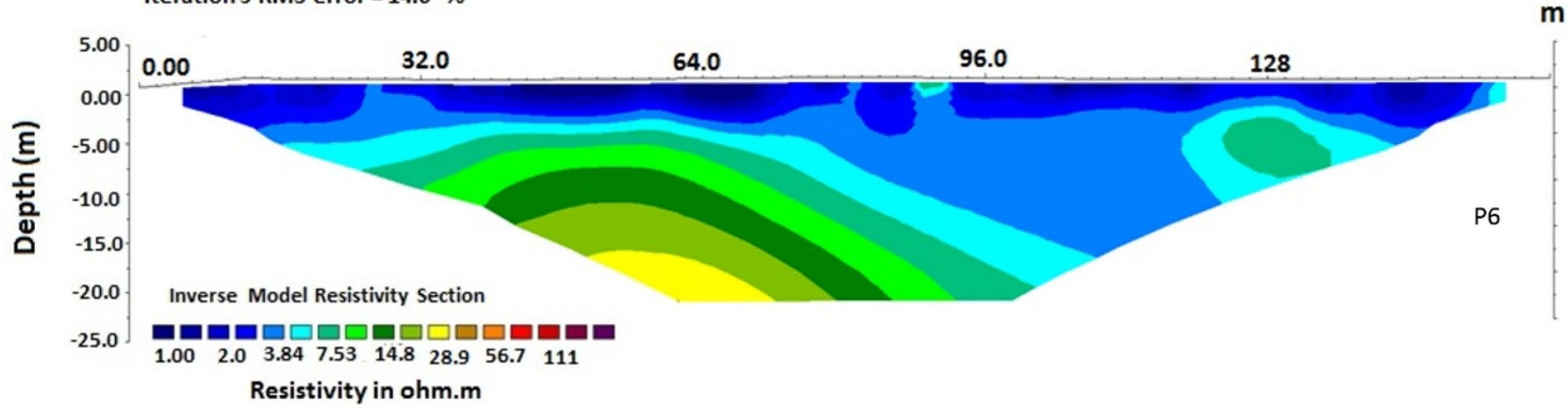

Fig. 6 Electrical Resistivity Imaging (ERI) profiles in Elandsdrift (P4-6) sites

described in the literature, resistivity data acquired in this work from the geo-electrical investigation, indicate the presence of strata saturated with seawater. However, it should be noted that Electrical Resistivity has a shortfall in distinguishing between a seawater saturated layer and a clay layer especially if they exist in the same formation (Satriani et al. 2012). In this case, geochemical analysis becomes crucial tool for the distinction between the two layers and to confirm the presence of seawater.

\section{Correlation of boreholes lithology with resistivity profiles}

To verify the geophysical results, to obtain the subsurface geological formation and to validate the reliability of the resistivity technique, new boreholes were drilled in the area of interest. Interpretation of the lithologs from the drilled boreholes indicates that the subsurface geology of the study site is made up of the following formations: from the upper 


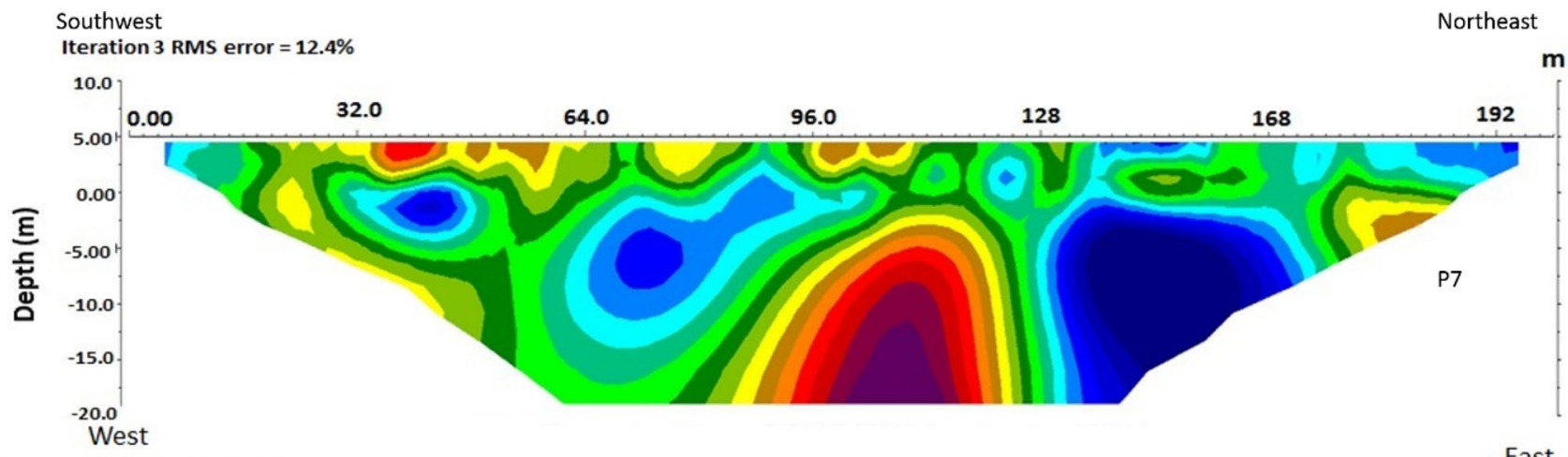

Iteration 3 KIMS error $=\mathbf{1 0 . 0} \%$

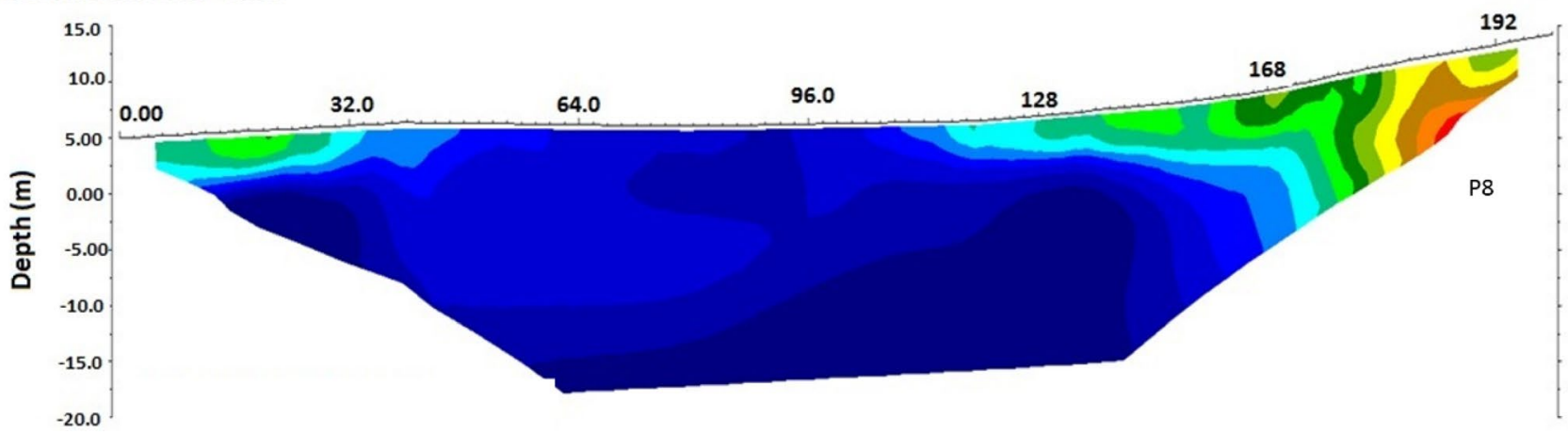

East

Iteration 3 RMS error $=31.5 \% \quad$ West

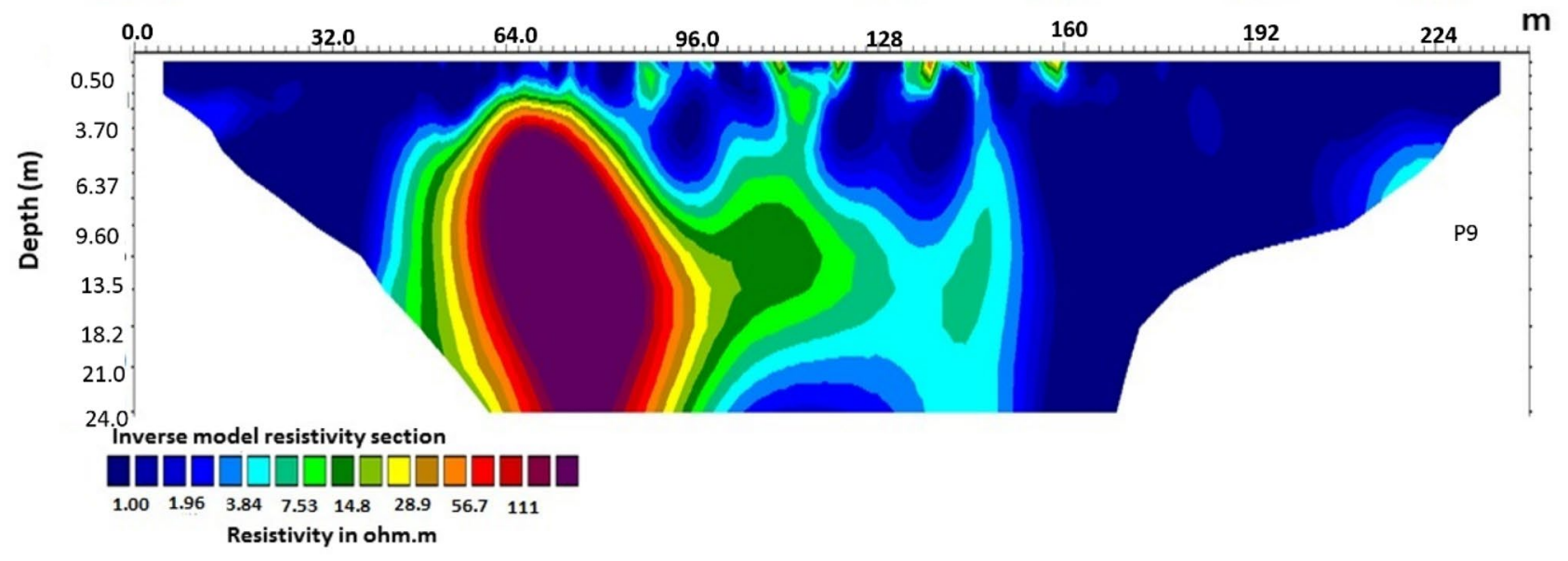

Fig. 7 Electrical Resistivity Imaging (ERI) profiles in Soetendalsvlei sites

surface, the sequence comprises of clay, loamy clay, fine sand, sandy clay, fine clay with rock chips, and sandy clay with marine shells, clay sand, shale and sandstone (Fig. 8).

The lithologs obtained during drilling are in agreement with the resistivity models and the geological setting of the area. In Soetendalsvlei BH3 corresponds with $\mathrm{P} 8$ at $75 \mathrm{~m}$ along the resistivity profile line, while PZ 17 (Fig. 8) correspond with $\mathrm{P} 9$ at $15 \mathrm{~m}$ and $\mathrm{BH} 2$ was drilled at $32 \mathrm{~m}$ in the same profile (Fig. 7). In Elandsdrift site, PZ 13 and 14 were drilled along P4 at 10 and $15 \mathrm{~m}$, respectively (Fig. 6). While in Voelvlei site PZ 4 and 3 were drilled along resistivity profile $\mathrm{P} 3$ at 10 and $14 \mathrm{~m}$, respectively (Fig. 5) and PZ1 corresponds with $\mathrm{P} 1$ at $192 \mathrm{~m}$. The general groundwater level in the study site varies from 2.2 to $3.8 \mathrm{~m}$ around Soetendalsvlei site whereas in Voëlvlei it varies from 0.5 to $4.4 \mathrm{~m}$ and in the Elandsdrift area the groundwater level recorded varies from 0.9 to $2.4 \mathrm{~m}$. Different subsurface materials were encountered during drilling (Fig. 8) of the piezometers and boreholes. Potential groundwater may be sourced from the sandstone and fine sand formations. From the resistivity models, a primary aquifer was identified at 8 and $30 \mathrm{~m}$ in the Soetendalsvlei site and upon drilling freshwater was 


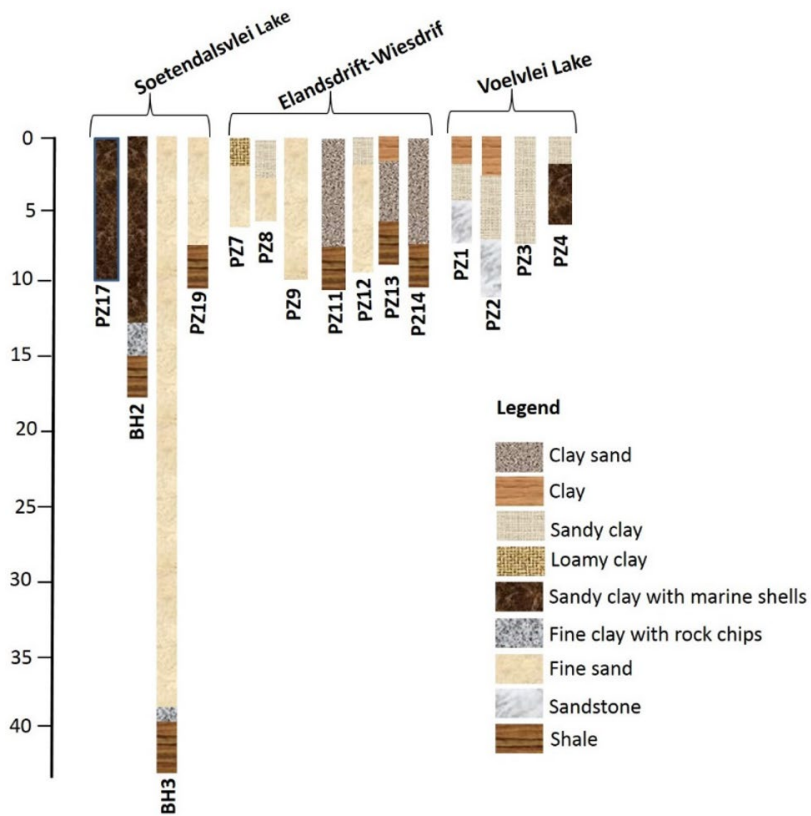

Fig. 8 Interpretation of subsurface geology from drilling logs

associated with these formations whereas saline water was associated with the clay layers.

\section{Hydrogeochemical investigation}

\section{Groundwater chemistry}

Table 2 indicates statistical and chemical analysis of major ions. The results show that $\mathrm{pH}$ values of the groundwater samples vary from 5.5 to 7.5 with a mean value of 7.1 , suggesting slightly acidic to alkaline groundwater in the area. The high alkalinity in groundwater of this area can be explained by the presence of considerable amounts of sodium, calcium, magnesium, and bicarbonate ions which are known to gradually increase the $\mathrm{pH}$ and alkalinity (Deshpande and Aher 2012) also the high $\mathrm{pH}$ is attributed to the passage of rivers through the limestone-bearing sands in the area. In the study area, TDS ranges from 907 to $48,977 \mathrm{mg} / \mathrm{l}$ with an average of $23,571 \mathrm{mg} / \mathrm{l}$ indicating a saline region. The high TDS values may be attributed to leaching of salts from quaternary sediments containing salts of sulphates and chlorides. Based on TDS classification of groundwater as suggested by Freeze and Cherry (1979), only 9.1\% (1) sample is classified as fresh (TDS $<1000 \mathrm{mg} / \mathrm{l}$ ) and $72.7 \%$ (8) of the samples are saline (TDS $10000-10,000 \mathrm{mg} / \mathrm{l}$ ); $18.2 \%$ (2) are brackish (TDS 1000-10,000 mg/l). This is in agreement with the resistivity profiles as they indicate that large coverage of the area is characterised by low resistivity values indicating shallow aquifers saturated with saline water. The high concentrations of TDS, $\mathrm{Cl}^{-}$and $\mathrm{Na}^{+}$may be associated with in-situ salinity from the overlying clay formations (Lagudu et al. 2013). Pure water is considered to have low EC. Usually EC determines the degree of dissolved matters in water. In the study site, the electrical conductivity ranges from 1354 to $73,100 \mu \mathrm{S} / \mathrm{cm}$ with mean value of $35,181 \mu \mathrm{S} /$ $\mathrm{cm}$. Salman and Elnazer (2015) mentioned that large variations of EC can be related to one or more processes, this includes but is not limited to rock-water interaction, reverse exchange, evaporation, ion exchange, silicate weathering, and anthropogenic activities like application of fertilizers. A previous study by Toens et al. (1998) reported high EC
Table 2 Chemical and statistical analysis of groundwater samples in Heuningnes Catchment

\begin{tabular}{lllllllllll}
\hline ID & PH & EC & TDS & $\mathrm{Na}^{+}$ & $\mathrm{K}^{+}$ & $\mathrm{Ca}^{2+}$ & $\mathrm{Mg}^{2+}$ & $\mathrm{SO}_{4}^{2-}$ & $\mathrm{Cl}^{-}$ & $\mathrm{HCO}_{3}^{-}$ \\
\hline PZ 2 & 7.4 & 35,400 & 23,718 & 5888 & 74 & 313 & 645 & 41 & 1413 & 186 \\
PZ 7 & 7.1 & 54,200 & 36,314 & 9040 & 50 & 258 & 280 & 941 & 18,659 & 152 \\
PZ 8 & 7.4 & 57,300 & 38,391 & 1107 & 56 & 249 & 290 & 348 & 16,408 & 164 \\
PZ 13 & 6.9 & 71,800 & 48,106 & 11,383 & 88 & 381 & 300 & 1609 & 40,988 & 230 \\
PZ 14 & 6.8 & 73,100 & 48,977 & 2625 & 40 & 70 & 190 & 300 & 4019 & 98 \\
PZ 15 & 6.9 & 29,300 & 19,631 & 4310 & 65 & 191 & 498 & 122 & 1896 & 188 \\
PZ 16 & 6.6 & 35,100 & 23,517 & 5966 & 72 & 262 & 707 & 152 & 2054 & 242 \\
PZ 19 & 7.1 & 1354 & 907 & 118 & 26 & 66 & 29 & 26 & 193 & 254 \\
PZ 22 & 7.5 & 15,860 & 10,626 & 2507 & 85 & 237 & 260 & 54 & 586 & 184 \\
BH1 & 7.3 & 11,260 & 7544 & 2120 & 78 & 67 & 150 & 1 & 3141 & 182 \\
BH 3 & 5.5 & 2320 & 1554 & 3575 & 86 & 211 & 220 & 318 & 5960 & 268 \\
Min & $\mathbf{5 . 5}$ & $\mathbf{1 3 5 4}$ & $\mathbf{9 0 7}$ & $\mathbf{1 1 8}$ & $\mathbf{2 6}$ & $\mathbf{6 6}$ & $\mathbf{2 9}$ & $\mathbf{1}$ & $\mathbf{1 9 3}$ & $\mathbf{9 8}$ \\
Max & $\mathbf{7 . 5}$ & $\mathbf{7 3 , 1 0 0}$ & $\mathbf{4 8 , 9 7 7}$ & $\mathbf{1 1 , 3 8 3}$ & $\mathbf{8 8}$ & $\mathbf{3 8 1}$ & $\mathbf{7 0 7}$ & $\mathbf{1 6 0 9}$ & $\mathbf{4 0 , 9 8 8}$ & $\mathbf{2 6 8}$ \\
STD & $\mathbf{0 . 6}$ & $\mathbf{2 6 , 1 4 2}$ & $\mathbf{1 7 , 5 1 5}$ & $\mathbf{3 4 1 7}$ & $\mathbf{2 0}$ & $\mathbf{1 0 4}$ & $\mathbf{2 0 8}$ & $\mathbf{4 9 4}$ & $\mathbf{1 2 , 4 2 3}$ & $\mathbf{5 0}$ \\
Mean & $\mathbf{7 . 0}$ & $\mathbf{3 5 , 1 8 1}$ & $\mathbf{2 3 , 5 7 1}$ & $\mathbf{4 4 2 2}$ & $\mathbf{6 5}$ & $\mathbf{2 1 0}$ & $\mathbf{3 2 4}$ & $\mathbf{3 5 6}$ & $\mathbf{8 6 6 5}$ & $\mathbf{1 9 5}$ \\
WHO & $\mathbf{6 . 5 - 9}$ & $\mathbf{1 5 0 0}$ & $\mathbf{1 5 0 0}$ & $\mathbf{2 0 0}$ & $\mathbf{1 2}$ & $\mathbf{2 0 0}$ & $\mathbf{1 5 0}$ & $\mathbf{2 5 0}$ & $\mathbf{2 5 0}$ & $\mathbf{5 0 0}$ \\
\hline
\end{tabular}

*Note all ions are in $\mathrm{mg} / \mathrm{l}$ and $\mathrm{EC}$ is in $\mu \mathrm{S} / \mathrm{cm}$ 
between 5000 and $10,000 \mu \mathrm{S} / \mathrm{cm}$ in groundwater associated with shales of the Bokkeveld formation. The groundwater around the Soetendalsvlei area has EC values varying between 4000 and 10,000 $\mu \mathrm{S} / \mathrm{cm}$, similarly high EC values were also recorded in the same area.

There are different dissolved inorganic constituents in water. The major cations are $\mathrm{Ca}^{2+}, \mathrm{Mg}^{2+}, \mathrm{Na}^{+}$and $\mathrm{K}^{+}$with mean value of $210,324,4422$ and $65 \mathrm{mg} / \mathrm{l}$, respectively (Table 2). The anions are $\mathrm{Cl}^{-}, \mathrm{SO}_{4}{ }^{2-}$ and $\mathrm{HCO}_{3}{ }^{-}$had mean values of 8665,356 and $195 \mathrm{mg} / \mathrm{l}$, respectively (Table 2). The dominance of $\mathrm{Na}^{+}$and $\mathrm{Cl}^{-}$ions in the groundwater could be in relation to leaching processes of highly soluble mineral salts associated with quaternary deposits in the study site. As explained by Salman and Elnazer (2015), the geochemical composition of groundwater provides a direct relation between the relative abundance of ions and the lithology. In terms of suitability for drinking water quality parameters ( $\mathrm{pH}$, TDS, $\mathrm{EC}, \mathrm{Ca}^{2+}, \mathrm{Mg}^{2+}, \mathrm{Na}^{+}, \mathrm{K}^{+}, \mathrm{Cl}^{-}$, $\mathrm{SO}_{4}^{2-}$ and $\mathrm{HCO}_{3}$ ) for this study have been compared with WHO (2011) standards for drinking water (Table 2). All the water samples are within the recommended limits for $\mathrm{pH}$ and $\mathrm{HCO}_{3}{ }^{-}$. Whereas, all the samples were above the allowable limit of $12 \mathrm{mg} / \mathrm{l}$ for $\mathrm{K}^{+}, 91 \%$ of the samples were beyond the limit of $(200,250,150,1500 \mathrm{mg} / \mathrm{l}$ and $1500 \mu \mathrm{S} / \mathrm{cm})$ for $\mathrm{Na}^{+}, \mathrm{Cl}^{-}, \mathrm{Mg}^{2+}$, TDS and EC, respectively. Only $63.6 \%$ are above the approved limit of $200 \mathrm{mg} / \mathrm{l}$ for $\mathrm{Ca}^{2+}$ and $45.5 \%$ exceeded $\mathrm{SO}_{4}{ }^{2-}$ permissible limit of $250 \mathrm{mg} / \mathrm{l}$, suggesting that groundwater in the area is not fit for drinking purposes due to high salinization.

\section{Hydrogeochemical evaluation}

Piper diagram: A Piper diagram is used to classify the groundwater with reference to hydro-geochemical processes (Khan and EghbalBakhtiari 2017) and dominant ions which reveal common composition and origin of ions in groundwater. In this diagram, the relative abundance of cations $\mathrm{Na}^{+}+\mathrm{K}^{+}, \mathrm{Ca}^{2+}$ and $\mathrm{Mg}^{2+}$ in $\%$ meq/l is plotted on the cation triangle followed by the relative abundance of anions $\mathrm{Cl}^{-}+\mathrm{NO}_{2}=\mathrm{NO}_{3}, \mathrm{SO}_{4}{ }^{2-}$ and $\mathrm{HCO}_{3}+\mathrm{CO}_{3}$ in $\%$ meq/l plotted on the anion triangle (Zaghlool and Eissa 2018). The overall chemical character of water is illustrated in the central diamond-shaped field (Piper 1953). Most of the samples fall in the $\mathrm{Na}^{+}-\mathrm{Cl}^{-}$field and only one sample falls in the mixed zone of $\mathrm{Ca}^{2+}-\mathrm{Mg}^{2+}-\mathrm{Cl}^{-}$type (Fig. 9).

\section{Correlation analysis}

Correlation analysis can be used to define the relationship of hydrochemical parameters in shallow groundwater chemistry in-terms of similarity and heterogeneity in their origins (Wen et al. 2020). A good relationship between two

Piper diagram of Heuninges Catchment
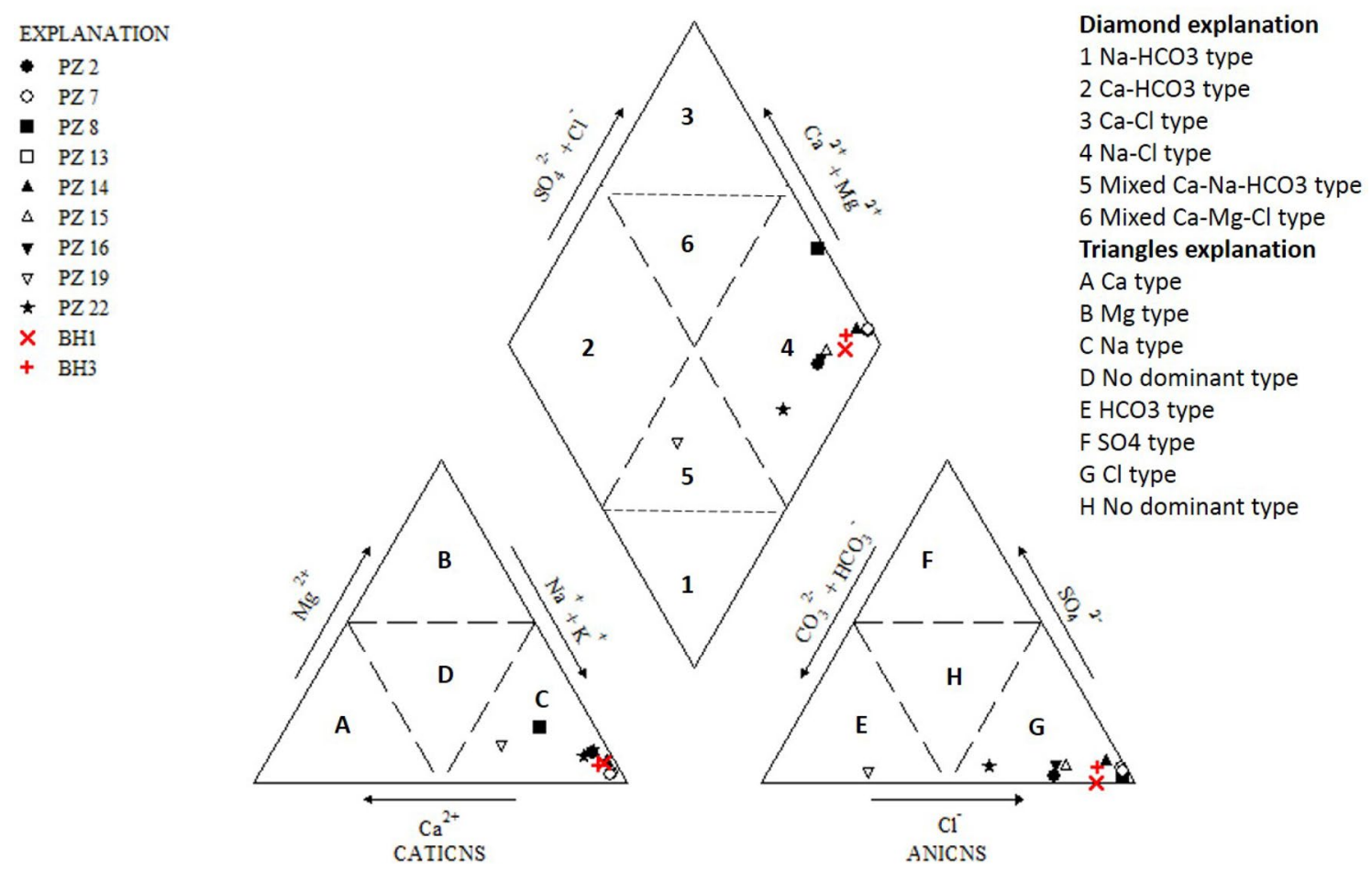

Fig. 9 Piper trilinear diagram indicating the groundwater type of the study site 
variables can be described by a high correlation coefficient near ( 1 or -1$)$. In this study, parameters with $r>0.7$ are considered to be strongly correlated, meanwhile parameters having ' $r$ ' between 0.5 and 0.7 stipulates moderate correlation. No relationship between parameters is indicated by $\mathrm{r}<0.05$. Table 3 shows that $\mathrm{Na}^{+}$is strongly correlated with $\mathrm{SO}_{4}{ }^{2-}$ and $\mathrm{Cl}^{-}$. Also a very strong correlation between $\mathrm{SO}_{4}{ }^{2-}$ and $\mathrm{Cl}^{-}$was observed. The high correlation between $\mathrm{Cl}^{-}$and $\mathrm{Na}^{+}$in most groundwater samples suggests that they originate from the same source. There is strong correlation between $\mathrm{Ca}^{2+}$ and $\mathrm{Na}^{+}$. Calcium has moderate correlation with $\mathrm{Cl}^{-}, \mathrm{Mg}^{+}, \mathrm{K}^{+}$and $\mathrm{SO}_{4}{ }^{2-}$. Both EC and TDS were also observed to have a moderate correlation with $\mathrm{Cl}^{-}, \mathrm{Na}^{+}$and $\mathrm{SO}_{4}{ }^{2-}$ suggesting that they have some sort of contribution to groundwater mineralization (Agoubi et al. 2013). In contrast, $\mathrm{HCO}_{3}{ }^{-}$has a poor correlation with all of the parameters; this trend was also observed in the $\mathrm{pH}$ which had a negative and poor relationship with all of the parameters in shallow groundwater. Based on the correlation analysis presented in Table 3, it can be concluded that the major parameters governing the groundwater chemistry in the area are TDS, $\mathrm{Cl}^{-}, \mathrm{Na}^{+}$and $\mathrm{SO}_{4}{ }^{2-}$, to some degree $\mathrm{Mg}^{2+}, \mathrm{K}^{+}$and $\mathrm{Ca}^{2+}$ played a role while $\mathrm{HCO}_{3}{ }^{-}$and $\mathrm{pH}$ had minor or no impact on the geochemistry.

\section{Gibbs diagram}

The Gibbs diagram can be used to display the evolution of groundwater composition and can indicate the mechanism that governs the chemical composition of groundwater, its evaporation, rock-water interaction or precipitation (Kumar 2016). Gibbs plots for this study using (TDS vs. $\mathrm{Na} /(\mathrm{Na}+\mathrm{Ca})$, and $\mathrm{Cl} /(\mathrm{Cl}+\mathrm{HCO} 3)$ suggest that evaporation is the main process controlling chemistry of the shallow groundwater (Fig. 10) and rock-water interaction had a minor influence in the shallow groundwater of the area. The dominance of evaporation process is quite common in semi-arid regions like the current study where the climatic condition of such regions tends to increase the evaporation rate thus causing a rise in $\mathrm{Na}^{+}, \mathrm{Cl}^{-}$and TDS contents, resulting in groundwater being saline (Mokoena et al. 2020). The Piper plot of the area also supports these findings as it indicated an increase in $\mathrm{Na}^{+}$and $\mathrm{Cl}^{-}$in the groundwater. According to Prasanna et al. (2010), anthropogenic activities such as agricultural fertilizers and irrigation-return flows tends to influence the evaporation by increasing $\mathrm{Na}^{+}$and $\mathrm{Cl}^{-}$and thus TDS, it could be true for the study area as it practices irrigation.

\section{Bivariate plots}

If the dissolutions of calcite, dolomite and gypsum are the foremost reactions in a system then the bivariate plot of $\mathrm{Ca}^{2+}+\mathrm{Mg}^{2+}$ versus $\mathrm{SO}_{4}{ }^{2-}+\mathrm{HCO}_{3}{ }^{-}$will be close to the 1:1 line (Kanagaraj et al. 2018; Kumar 2016). If the points shift more to the left due to an excess of $\mathrm{SO}_{4}{ }^{2-}+\mathrm{HCO}_{3-}$ this indicates ion-exchange as a result of silicate weathering. The groundwater samples in the study area indicate enrichment of $\mathrm{Ca}^{2+}+\mathrm{Mg}^{2+}$ compared to $\mathrm{HCO}_{3}{ }^{-}$, these points are more to the right below the $1: 1$ line indicting that reverse ion-exchange processes dominate in the area (Fig. 11) and that this occurs due to the weathering of carbonate minerals in the presence of clays with exchangeable $\mathrm{Ca}^{2+}$ (Papazotos et al. 2019).

The $\mathrm{Na}^{+}$vs $\mathrm{Cl}^{-}$plot reveals enrichment of $\mathrm{Na}^{+}$in groundwater samples. The $\mathrm{Na} / \mathrm{Cl}$ ratio ranged from 0.1 to 6.6 with a mean value of 2.4. Occurrence of halite dissolution process depends on the $\mathrm{Na} / \mathrm{Cl}$ ratio being equal to 1 , however, in this study, most of the $\mathrm{Na}^{+} / \mathrm{Cl}^{-}$ratios were above 1 indicating another source responsible for $\mathrm{Na}^{+}$enrichment in groundwater. According to Mohanty and Rao (2019), high levels of $\mathrm{Na}^{+}$content in groundwater propose the presence of background level of $\mathrm{Na}^{+}$ which originates from the weathering of aquifer material such as sodium-bearing minerals in the aquifer matrix and later released by the cation-exchange processes in the clay
Table 3 Correlation of groundwater samples in Heuningnes Catchment

\begin{tabular}{lllllllllll}
\hline & $\mathrm{pH}$ & $\mathrm{EC}$ & $\mathrm{TDS}$ & $\mathrm{Ca}^{2+}$ & $\mathrm{Mg}^{2+}$ & $\mathrm{Na}^{+}$ & $\mathrm{K}^{+}$ & $\mathrm{Cl}^{-}$ & $\mathrm{SO}_{4}^{2-}$ & $\mathrm{HCO}_{3}^{-}$ \\
\hline $\mathrm{pH}$ & 1 & & & & & & & & \\
$\mathrm{EC}$ & 0.2 & 1 & & & & & & & & \\
$\mathrm{TDS}$ & 0.2 & 1 & 1 & & & & & & & \\
$\mathrm{Ca}^{2+}$ & 0.01 & 0.39 & 0.38 & 1 & & & & & & \\
$\mathrm{Mg}^{2+}$ & 0 & 0.18 & 0.18 & 0.58 & 1 & & & & & \\
$\mathrm{Na}^{+}$ & -0.1 & 0.52 & 0.52 & $\mathbf{0 . 7 4}$ & 0.4 & 1 & & & & \\
$\mathrm{~K}^{+}$ & -0.19 & -0.12 & -0.12 & 0.56 & 0.35 & 0.38 & 1 & & & \\
$\mathrm{Cl}^{-}$ & 0 & 0.63 & 0.63 & 0.6 & -0.1 & $\mathbf{0 . 7}$ & 0.22 & 1 & & \\
$\mathrm{SO}_{4}^{2-}$ & -0.11 & 0.64 & 0.64 & 0.58 & -0.08 & $\mathbf{0 . 8}$ & 0.18 & $\mathbf{0 . 9 6}$ & 1 & \\
$\mathrm{HCO}_{3}^{-}$ & -0.59 & -0.59 & -0.59 & 0.21 & 0.06 & 0.06 & 0.31 & 0.02 & 0.02 & 1 \\
\hline
\end{tabular}

* Note all ions are in $\mathrm{mg} / \mathrm{l}$ and $\mathrm{EC}$ is in $\mu \mathrm{S} / \mathrm{cm}$, 
Fig. 10 Gibbs plot for the study area

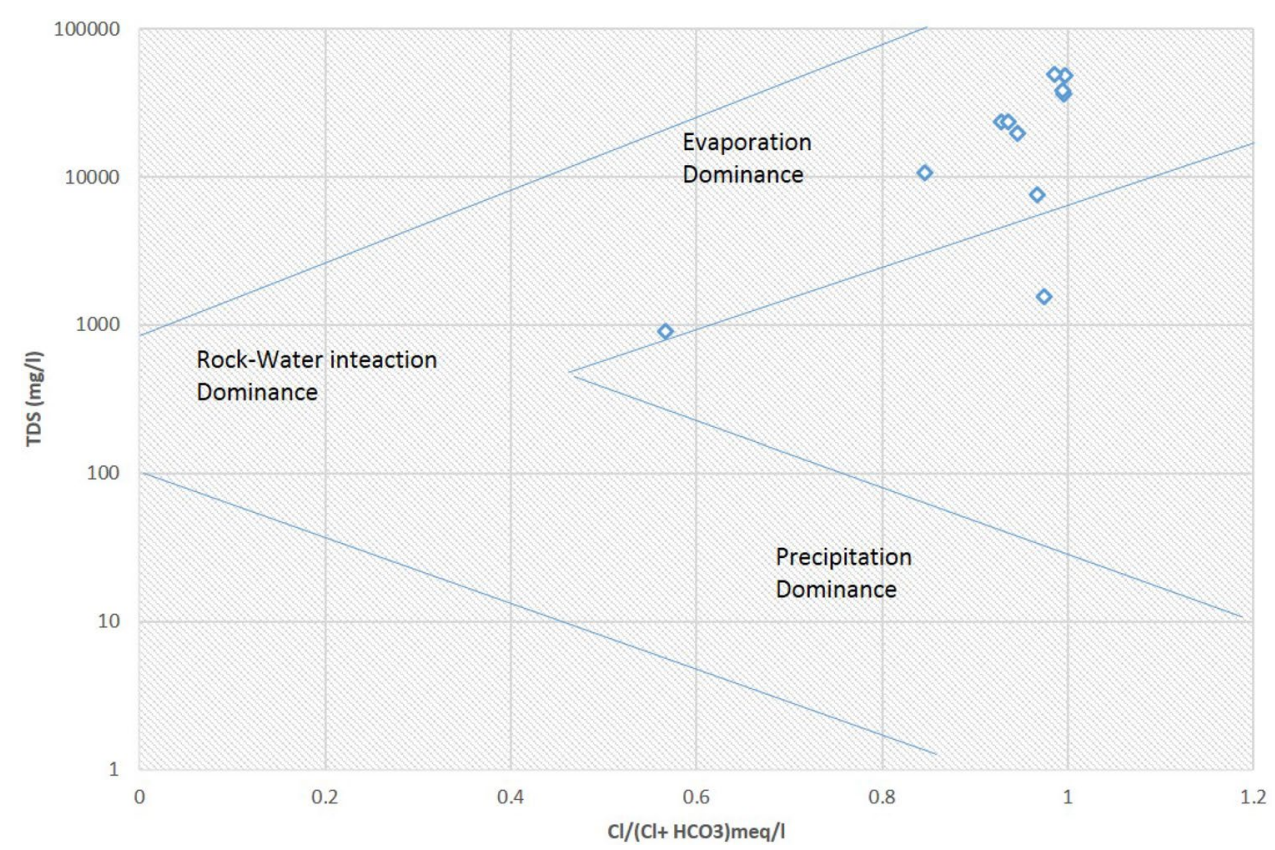

Indication of salinization

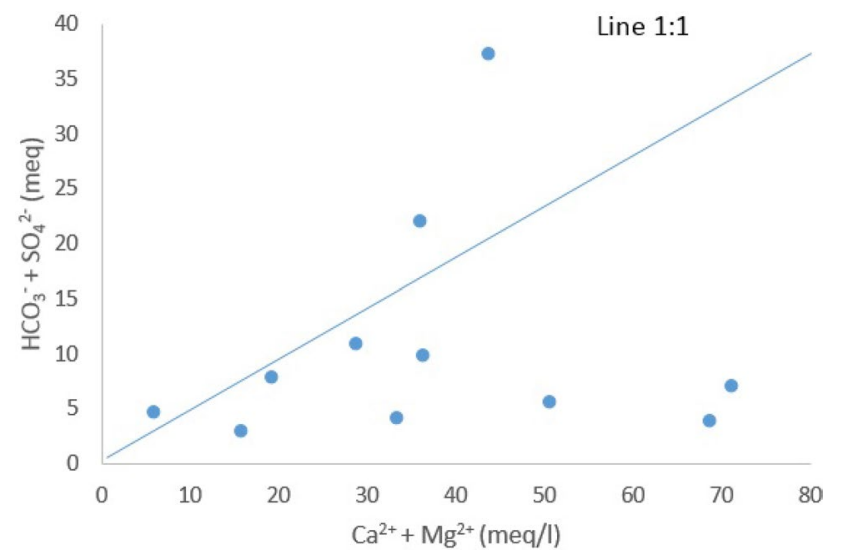

Fig. 11 Bivariate plot of $\mathrm{Ca}^{2+}+\mathrm{Mg}^{2+}$ versus $\mathrm{SO}_{4}{ }^{2-}+\mathrm{HCO}_{3}{ }^{-}$showing reverse ion exchange

minerals that constitute the matrix of sediments in coastal aquifers. Most of the samples plot away from the mixing line and there is no linear relationship between $\mathrm{Na}^{+}$and $\mathrm{Cl}^{-}$(Fig. 12) suggesting that the samples are not from the same source of origin and seawater is not the influence of groundwater in the aquifer. Therefore, the fact that the majority of the samples were found to be above the theoretical mixing 1:1 line insinuates that cation-exchange processes modified the groundwater chemistry by replacing it with $\mathrm{Ca}^{2+} /$ and $\mathrm{Mg}^{2+}$ (Papazotos et al. 2019; Kumar 2016).
To avoid misinterpretation of the $\mathrm{Na}^{+} / \mathrm{Cl}^{-}$type to only seawater intrusion, ionic molar ratios of $\mathrm{Na}^{+} / \mathrm{Cl}^{-}$and $\mathrm{SO}_{4}{ }^{2-} / \mathrm{Cl}^{-}$are applied to distinguish the origin of salinity in groundwater. Salinity ingress from the sea can be confirmed by analysing the shifts in molar ratios of ions (Nair et al. 2015). Seawater is characterized by the dominance of $\mathrm{Na}^{+}$ and $\mathrm{Cl}^{-}$with total dissolved solids of about $35,000 \mathrm{mg} / \mathrm{L}$, of which $19,000 \mathrm{mg} / \mathrm{L}$ of it is chloride according to Klassen et al. (2014). Groundwater in boreholes affected by seawater generally have $\mathrm{Na}^{+} / \mathrm{Cl}^{-}$ratios less than 0.86 . Ratios above 1 indicate groundwater that is polluted by anthropogenic sources, agricultural activities and geo-chemical processes (Zaghlool and Eissa 2018). The molar ratios of $\mathrm{Na}^{+} / \mathrm{Cl}^{-}$, $\mathrm{SO}_{4}{ }^{2-} / \mathrm{Cl}^{-}$and $\mathrm{Mg}^{2+} / \mathrm{Ca}^{2+}$ for the study are tabulated in Table 4. The $\mathrm{Na}^{+} / \mathrm{Cl}^{-}$ratio for this study ranges from 0.1 to 6.60 and differs significantly from that of the general seawater $(0.86)$. The samples indicate a ratio of less than or slightly higher than this ratio suggesting that salinity is from other sources. About 54.5\% (5) of the tested samples indicate $\mathrm{Na}^{+} / \mathrm{Cl}^{-}$ratio above 1 suggesting an influence of rock-water interaction and possible weathering of alkali feldspars in the aquifer according to Mohanty and Rao (2019). This also suggests a possible contribution of recent recharge from precipitation reflecting meteoric origin. The remaining samples (PZ7, PZ8 and PZ 13) have ratios much lower than 0.86 , and these could be attributed to reverse ion exchange reactions with clay minerals exchanging $\mathrm{Na}^{+}$for $\mathrm{Ca}^{2+}$ and $\mathrm{Mg}^{2+}$ which is a common phenomenon in saline groundwater (Mtoni 2013; Nwankwoala 2013, Alfarrah and Walraevens 2018). According to Nair et al. (2015), low $\mathrm{Na}^{+} /$ 
Fig. 12 Bivariate plots of $\mathrm{Na}^{+}$ vs $\mathrm{Cl}^{-}$

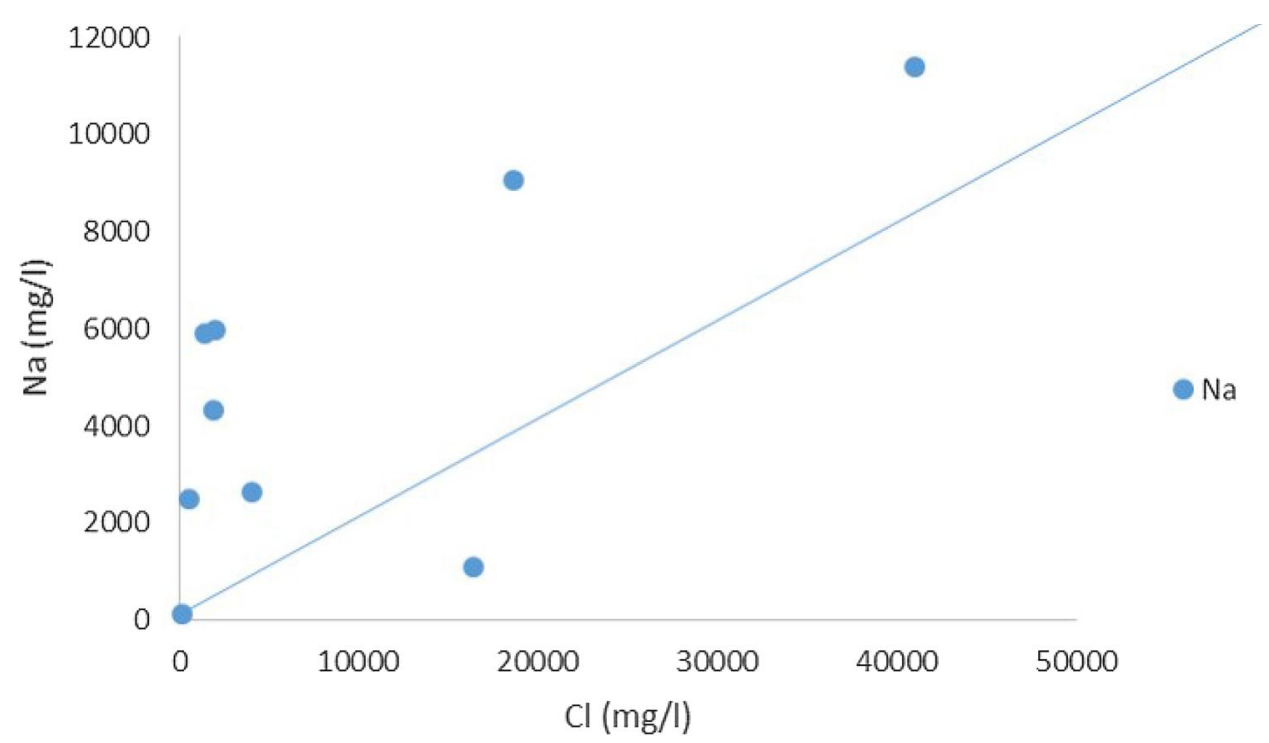

Table 4 Ionic ratios

\begin{tabular}{llll}
\hline ID & $\mathrm{SO}_{4}{ }^{2-} / \mathrm{Cl}^{-}$ & $\mathrm{Na}^{+} / \mathrm{Cl}^{-}$ & $\mathrm{Mg}^{2+} / \mathrm{Ca}^{2+}$ \\
\hline PZ 2 & 0.02 & 6.43 & 3.39 \\
PZ 7 & 0.04 & 0.75 & 1.79 \\
PZ 8 & 0.02 & 0.10 & 1.92 \\
PZ 13 & 0.03 & 0.43 & 1.30 \\
PZ 14 & 0.06 & 1.01 & 4.48 \\
PZ 15 & 0.05 & 3.51 & 4.31 \\
PZ 16 & 0.06 & 4.48 & 4.46 \\
PZ 19 & 0.10 & 0.94 & 0.73 \\
PZ 22 & 0.07 & 6.60 & 1.81 \\
BH1 & 0.00 & 1.04 & 3.69 \\
BH 3 & 0.04 & 0.93 & 1.72 \\
\hline
\end{tabular}

* Note all ions are in meq/l

$\mathrm{Cl}^{-}$in conjunction with other geochemical constituents show seawater intrusion, even at fairly low chloride concentrations, in early stages of salinization.

High concentration of $\mathrm{Mg}^{2+} / \mathrm{Ca}^{2+}$ ratio is attributed to seawater intrusion and the range for $\mathrm{Mg}^{2+} / \mathrm{Ca}^{2+}$ ratio in seawater is between $4.5-5.2$ with an excess of $\mathrm{Mg}^{2+}$ as given by Nair et al. (2015). The groundwater samples which were tested indicate $\mathrm{Mg}^{2+} / \mathrm{Ca}^{2+}$ ratios above 1 (Table 4) however, they fall below the seawater range implying that other sources are responsible for salinization of groundwater such as (reverse cation exchange, dolomite dissolution processes or sewage invasion). To define freshwater and seawater mixing $\mathrm{SO}_{4}{ }^{2-} / \mathrm{Cl}^{-}$ratio is used as a natural tracer, in seawater the value of $\left(\mathrm{SO}_{4}{ }^{2-} / \mathrm{Cl}^{-}\right)$* 1000 is found to be 103.4 and, as established from these values the quality of groundwater can be classified into two clusters (i) samples with a $\mathrm{SO}_{4}{ }^{2-} / \mathrm{Cl}^{-}$ratio similar to seawater, and (ii) samples with a ratio of $\mathrm{SO}_{4}{ }^{2-} / \mathrm{Cl}^{-}$ratio more than 300 , mainly influenced by dissolution of evaporates according to Mallick et al. (2018). In the present study, the ratio of $\left(\mathrm{SO}_{4}{ }^{2-} / \mathrm{Cl}^{-}\right) *$ 1000 ranges from 0 to 100; none of the samples are above 300 indicating no influence of seawater on groundwater. They are however close to 103.4 indicating early stages of intrusion. Also Lagudu et al. (2013) suggest that $\mathrm{SO}_{4}{ }^{2-} / \mathrm{Cl}^{-}$ratio $>0.05$ is an indication of seawater intrusion, this ratio could go up to 0.1. Following this suggestion, six samples (PZ2, PZ7, PZ 8, PZ 13, BH 1, BH3) were lower than this ratio, showing that these sites are slightly affected by seawater probably from deep saline upconing (Lagudu et al. 2013). Whereas five samples (PZ 14, PZ 15, PZ 16, PZ 19, PZ 22) were within the 0.05 -0.1 range of seawater intrusion.

The bivariate plots suggest that reverse ion-exchange and cation exchange processes seem to control the chemistry of groundwater in the area. Overall assessment of the ionic ratios suggests that only three samples (PZ7, PZ8 and PZ 13) indicate signs of seawater intrusion based on lower $\mathrm{Na}^{+} / \mathrm{Cl}^{-}$ratios and a TDS value above $35000 \mathrm{mg} / \mathrm{L}$, only PZ 13 has $\mathrm{Cl}^{-}$above the $19000 \mathrm{mg} / \mathrm{l}$ described for $\mathrm{Cl}^{-}$in seawater. It could be that these wells are experiencing early stages of seawater intrusion or are in the transition phase. In the literature, a transition zone is characterised by TDS of $1000-35000 \mathrm{mg} / \mathrm{L}$ and 250- $19000 \mathrm{mg} / \mathrm{L}$ of Chloride; higher values indicate seawater intrusion (Klassen et al. 2014). Only four samples exceed the transition range for TDS and the remaining samples are within the transition zone and two exceed the $19000 \mathrm{mg} / \mathrm{L}$ for $\mathrm{Cl}^{-}$. This confirms salinization in the area and perhaps may be an indication of early stages of seawater intrusion.

\section{Discussion}

Integration of hydrogeological, hydrochemical and geophysical data is an effective approach to investigate saline groundwater in coastal aquifers, seawater intrusion, and 
contaminated zones according to Lagudu et al. (2013). Coupling of these data sets decreases uncertainty of the ERI interpretation and increase its reliability. $\mathrm{Cl}^{-}$and $\mathrm{Na}^{+}$ ions are the most observed parameters in the evaluation of seawater intrusion in coastal aquifers because they are the most dominant ions in seawater (Sae-Ju et al. 2018). Many studies have associated high concentrations of these ions due to influence of seawater intrusion (Rao et al. 2011). Also a resistivity value of less than $10 \Omega \mathrm{m}$ is often used as an indicator of seawater intrusion. Supriyadi and Putro (2017) conducted geophysical and hydrochemical studies in Tanah Mas Residential area of North Semarang, Indonesia to define subsurface geological formations and evaluate intrusion of seawater. Their findings indicate that three boreholes had elevated concentrations of $\mathrm{Na}^{+}$and $\mathrm{Cl}^{-}$and this was associated with seawater intrusion, in support the resistivity value of $<1 \Omega \mathrm{m}$ confirmed seawater in their area. A study by Rao et al. (2011) found similar results where they encountered high chloride, TDS, and sodium concentrations at Surasaniyanam, Vodalarevu, Devaguptham, Vasalatippa, and N. Kottapalli villages. They attributed these higher concentrations to seawater from the high tides, intruding in the Pikaleru, Kanavaram, and Vasalatippa drains; the low resistivity was due to the encroachment of seawater into the freshwater zones in their area. In this study, most of the resistivity profiles have low resistivity of $1-3 \Omega \mathrm{m}$ indicating the subsurface is saturated with saline water. The low resistivities were associated with clay, and fine sands saturated with saline water formations. These low resistivities were later confirmed by high concentration of TDS (>1000 mg/l), EC, $\mathrm{Cl}^{-}$and $\mathrm{Na}^{+}$values which indicate salinization of groundwater samples taken from these formations. Chemical analysis from the Piper diagram shown dominance of $\mathrm{Na}-\mathrm{Cl}$ water type in the region.

The findings from resistivity investigation depicts subsurface formation of the study area dominated by low resistive value $<3 \Omega \mathrm{m}$ interpreted as clay layers in all three sites. This presents a challenge in terms of distinguishing seawater-infiltrated zones, because both seawater and clay are conductive, and therefore will reflect low resistivity values lower than $3 \Omega \mathrm{m}$. To avoid misinterpretation of seawater intrusion when using ERI, ionic ratios were considered in conjunction with chemical analysis to get the distinction. As indicated in the literature, resistivity lower than $10 \Omega \mathrm{m}$ suggests the presence of seawater intrusion in coastal aquifers. The low resistivity values below $3 \Omega \mathrm{m}$ in the area could be attributed to seawater intrusion however, this is not true in all locations as the ionic analysis suggests other processes than seawater intrusion. Therefore, high salinity observed in the area is a result of the geological setting as discussed in Sect. 3, weathering of rock especially from the underlying Bokkeveld shales. Also, trapped saline-water within the aquifer which got enriched with the ions over time may have some contribution to the salinity. The Gibbs plot suggested that the evaporation process is the main influence of groundwater quality in the area along with rock-water interaction. A study by Mazvimavi (2018) also discovered that water quality in the area is influenced by evaporitic processes from nearby wetlands with almost no groundwater through-flow. Salinization in the area is a result of combined effects of geochemical processes, geological condition and possible seawater influence in certain areas based on resistivity data. The ionic ratio analyses further suggests that the sites PZ 7, PZ 8 and PZ13 are influenced by seawater intrusion as they have $\mathrm{Na}^{+} / \mathrm{Cl}^{-}$ratio lower than 0.86 . These results explain the prevailing of low resistivity found in most of the profile lines. These sites also had the highest $\mathrm{Na}^{+}$, $\mathrm{Cl}^{-}, \mathrm{SO}_{4}{ }^{2-}$, and TDS which confirms that the area might be experiencing early stages of seawater intrusion. According to (Lagudu et al. 2013), samples which have ionic ratios above the standard seawater ratio for $\mathrm{Na}^{+} / \mathrm{Cl}^{-}$and $\mathrm{SO}_{4}{ }^{2-} / \mathrm{Cl}^{-}$as defined in the literature, does not only insinuate anthropogenic influence as a sole process without influence of seawater intrusion. A reasonably explanation is that an overlap occurred between groundwater contamination processes, which normally take place when more than one pollutant from a variety of sources simultaneously occur in the aquifer which might be the case in the Heuningnes Catchment.

An additional source contributing to the high salinity levels in the investigated area, especially in the Soetendalsvlei, could be saline water recharge from the salt pan known as Soutpan which is situated on the western site of the Soetendalsvlei. Taking into consideration also the activities taking place in the area such as agricultural practices, the fertilizers used during these practices also contribute to salinization especially on the upper layers of the subsurface of the study site or rather on the shallow aquifers of the Heuningnes Catchment.

\section{Conclusion}

A multi-approach technique of integrating geological, geophysical and chemical datasets for a comprehensive investigation of salinity prevailing in the Heuningnes Catchment was applied. Using this approach in the area, the 2D geoelectrical resistivity models provided significant insight on the area's subsurface geology and the distribution of saline, brackish and fresh water within the shallow aquifer. The assessment of lithological logs obtained during drilling of boreholes and piezometers indicates that the study region is characterized by alternating layers of sandy clays, clays, fine sands, loamy clay, sandstone and shales of various degree of weathering which coincide with the findings of the resistivity results. The resistivity models revealed a dominant trend of increasing resistivity with depth, indicating that salinity 
decreases with depth. Also the variation in resistivity that was observed in the study site is a result of the different lithologic types, water content and the amount of dissolved solids present. Hydrogeochemical investigation of the groundwater samples indicates slightly acidic to alkaline water because of high EC, TDS and $\mathrm{Cl}$ contents. Furthermore, use of the Piper diagram indicated $\mathrm{Na}-\mathrm{Cl}$ type as the principal groundwater type in the area, which attests the salinity. Analysis of ionic ratios of $\mathrm{Na}^{+} / \mathrm{Cl}^{-}$and $\mathrm{SO}_{4}{ }^{2-} / \mathrm{Cl}^{-}$suggest that salinity in the area is not a consequence of seawater intrusion only in most parts, but rather the result of dissolution of evaporates and dilution of marine clays rich in sodium. The bivariate plots suggest that reverse ion exchange is the main process controlling the chemistry of shallow groundwater, in addition the Gibbs diagram indicated evaporation as the main processes controlling geochemistry aided by rock-water interaction.

The general groundwater quality in the area is not apt for drinking due to high salinization, most of the samples indicated high concentration levels of TDS, $\mathrm{Na}^{+}$and $\mathrm{Cl}^{-}$above the recommended limits as per WHO (2011) standards. Groundwater pumping in Soetendalsvlei is not recommended except in P7 and P10 due to high salinity. However, at Elandsdrift site and some parts of the Voëlvlei site pumping can be allowed. It is recommended that a resistivity survey with additional electrodes be carried out in the area to gain deeper insights at greater depths beyond the one which was covered here, to further investigate seawater intrusion.

This study demonstrated that an integrated approach of resistivity data with well-log data coupled with the chemical analysis is efficient in comprehending the extent and origin of groundwater salinity in coastal aquifers. Since this survey was conducted during the wet season, repetition of the same survey is recommended to be conducted during the dry season to determine the reliability of the method and to validate the results. Based on the overall assessment of resistivity data, ionic analysis and chemical interpretation, it could be concluded that larger parts of the area are a transition zone and only few locations are actually impacted by seawater intrusion. This is supported by the high levels of TDS, $\mathrm{Na}^{+}$ and $\mathrm{Cl}^{-}$and very low resistivity values. Therefore, more detailed chemical data from additional boreholes around the area are needed to further explore the influence of seawater in the groundwater. Perhaps isotope investigation could be more useful in providing clarity on seawater-groundwater interaction.

Acknowledgements The authors of this paper would like to acknowledge the following people for their great assistance in this study $\mathrm{M}$ de Klerk, Environmental Water Science research team and Water Research Commission (WRC) for funding the study.

Author contributions PM was responsible for drafting of the article, conception and design, acquisition, analysis and interpretation of data,
JvBD and TK were responsible for reviewing, revising and for the final approval of the article, KM was responsible for acquisition and reviewing of data.

\section{Compliance with ethical standards}

Conflict of interest The authors would like to declare no conflict of interest.

\section{References}

Adepelumi AA, Ako BD, Ajayi TR, Afolabi O, Omotoso EJ (2009) Delineation of saltwater intrusion into the freshwater aquifer of Lekki Peninsula, Lagos. Nigeria Environ Ear Sci 56(5):927-933

Agoubi B, Kharroubi A, Abichou T, Abida H (2013) Hydrochemical and geoelectrical investigation of Marine Jeffara Aquifer, southeastern Tunisia. Appl Water Sci 3:415-429. https://doi. org/10.1007/s13201-013-0091-4

Alfarrah N, Walraevens K (2018) Groundwater Overexploitation and Seawater Intrusion in Coastal Areas of Arid and Semi-Arid Regions. Water Journal. https://doi.org/10.3390/w10020143

Bouderbala A, Remini B, Hamoudi AB (2016) Geoelectrical investigation of saline water intrusion into freshwater aquifers: a case study of Nador coastal aquifer,Tipaza, Algeria

Deshpande SM, Aher KR (2012) Evaluation of Groundwater Quality and its Suitability for Drinking and Agriculture use in Parts of Vaijapur, District Aurangabad, MS. India Res J Chem Sci 2(1):25-31

Dushiyanthan C, Raja J, Kumar T, Karthikeyan K, Raju D, Thiruneelakandan B, Suresh R (2014) Assessment of shallow Aquifer Potentialzone using ElectricalResistivity Scanning Techniques Compare with Borehole Lithology in We stern part of Lower Vellar basin, Chidambaram Taluk, Cuddalore, Tamilnadu, India. Int. Res. J Earth Sci 2(2), 30-34, March

Felisa G, Ciriello V, Di Federico V (2013) Saltwater Intrusion in Coastal Aquifers: A Primary Case Study along the Adriatic Coast Investigated within a Probabilistic Framework. Journal of water 5:1830-1847

Freeze RA, Cherry JA (1979) Groundwater. Prentice-Hall Inc., Englewood Cliffs, p 604.

Gaaloul N, Pliakas F, Kallioras A, Schuth C, Marinos P (2012) Simulation of Seawater Intrusion in Coastal Aquifers: Forty Five-Years Exploitation in an Eastern Coast Aquifer in NE Tunisia. J Hydrol 6:31-44

Hamdan H, Kritikakis G, Andronikidis N, Economou N, Manoutsoglou E, Vafidis A (2010) Integrated geophysical methods for imaging saline karst aquifers. A casestudy of Stylos, Chania, Greece. Journal of the Balkan Geophysical Society 13(1), p. 1-8, 6

Hazreek ZA, Hashim MMM, Asmawisham AM, Hafiz N, Fairus ZM, Fahmy YM, Ashraf KA, Rosli MI, Nordiana MM (2018) Seawater Intrusion Mapping using Electrical Resistivity Imaging (Eri) at Malaysian Coastal Area. Int J of Civil Eng Tech 9(9):1185-1193

Herdien EL, Petersen C, Reed C, Impson D, Belcher A, Ndiitwani T, Buthelezi S, Matoti A (2005) Technical Report: Ecological Status for Rivers of the Overberg Region 2004/2005 HilL and associates 2008. Situation assessment for Heuningnes Estuary. Report AGU07/596/02 pp1-36

Hodlur GK, Dhakate R, Sirisha T, Panaskar DB (2010) Resolution of freshwater and saline water aquifers by composite geophysical data analysis methods. Hydrol Sci J 55(3):414-434. https://doi. org/10.1080/02626661003738217 
Johnson TA, Matsumoto N, Jansen JR (2008) Time Domain Electromagnetic Induction and High Resolution Electric Resistivity Soundings to Map Salt Water Intrusion in Coastal Sandy Aquifers, Los Angeles County, California. 20th Salt Water Intrusion Meeting June 23-27, Naples, Florida, USA.

Kanagaraj G, Elango L, Sridhar SGD, Gowrisankar G (2018) Hydrogeochemical processes and influence of seawater intrusion in coastal aquifers south of Chennai. Environ Sci Pollut Res, Tamil Nadu, India. https://doi.org/10.1007/s11356-017-0910-5

Kelly BB (2011) Using Electrical Resistivity Imaging to Map Saline Groundwater and Subaqueous Spring Discharge: An Example from the Saline Wetlands of Eastern Nebraska. Dissertation, University of Nebraska, pp 161

Khan A, EghbalBakhtiari A (2017) Groundwater Assessment of Coastal Aquifers in Karachi: Impact of Seawater Intrusion. Int. J. of Ground Sediment and Water 6

Klassen J, Allen DM, Kirste D (2014) Chemical Indicators of saltwater intrusion for the gulf islands, British Columbia. Report, Simon Fraser University

Kumar PJS (2016) Deciphering the groundwater-saline water interaction in a complex coastal aquifer in South India using statistical and hydrochemical mixing models. Model Earth Syst Environ 2:194. https://doi.org/10.1007/s40808-016-0251-2

Lagudu S, Rao VVSG, Sarma VS, Prasad PR (2013) Use of Geophysical and Hydrochemical Tools to Investigate Seawater Intrusion in Coastal Alluvial Aquifer, Andhra Pradesh, India. https://doi.org/10.1007/978-94-007-5648-9_4

Lewis AL, Lautier JC, Wilson NC, Chianese G, Webb S (2004) Geophysical monitoring and evaluation of coastal plain aquifers. National groundwater association 42(1):59-67

Loke MH (1999) Electrical imaging surveys for environmental and engineering studies, user manual for Res2dinv Electronic version available from http://www.geometrics.com

MacQuarrie K, Butler K, Mott E, Green N (2012) A case study of coastal aquifers near Richibucto, New Brunswick: Saline groundwater occurrence and potential impacts of climate change on seawater intrusion. pp 1-18

Mallick J, Singh CK, AlMesfer MK, Kumar A, Khan RA, Islam S, Rahman A (2018) Hydro-Geochemical Assessment of Groundwater Quality in Aseer Region, Saudi Arabia Water journal, 10, 1847; https://doi.org/10.3390/w10121847

Mazvimavi D (2018) Finding "new" water to address conflicting and competing water demands in the Nuwejaars Catchment, Cape Agulhas. WRC report no 2324/1/18, pp135

Meyer PS (2001) An Explanation of the 1:500 000 General Hydrological Map of Cape Town

Mogren S (2015) Saltwater Intrusion in Jizan Coastal Zone, Southwest Saudi Arabia, Inferred from Geoelectric Resistivity Survey. Int J of Geosciences 6:286-297

Mohanty AK, Rao VVSG (2019) Hydrogeochemical, seawater intrusion and oxygen isotope studies on a coastal region in the Puri District of Odisha, India. CATENA 172:558-571. https://doi. org/10.1016/j.catena.2018.09.010

Mokoena P, Kanyerere T, van Bever DJ (2020) Hydrogeochemical characteristics and evaluation of groundwater quality for domestic and irrigation purposes: a case study of the Heuningnes Catchment, Western Cape Province. South Africa SN Applied Sciences 2:1548. https://doi.org/10.1007/s42452-020-03339-0

Mtoni Y (2013) Saltwater intrusion in the coastal strip of Dar es Salaam Quaternary aquifer, Tanzania. Dissertation, Ghent University, Faculty of Sciences, Belgium, 395 pp

Nair IS, Rajaveni SP, Schneider M, Elango L (2015) Geochemical and isotopic signatures for the identification of seawater intrusion in an alluvial aquifer. J Earth Syst Sci 124(6):1281-1291
Nwankwoala HO (2013) Ionic Abundance and Distributions in Groundwater Systems: A Case Study. Greener Journal of Physical Sciences 3(4):115-130

Ohwoghere- Asuma O, Akpoborie IA, Akpokodje EG (2014) Investigation of Saltwater Intrusion in Warri -Effurun Shallow Groundwater Aquifer from 2D Electrical Resistivity Imaging and Hydraulic Gradient Data. New York Science Journal 7(12): 20 29]. (ISSN: 1554-0200). http://www.sciencepub.net/newyo $\mathrm{rk}$

Oyeyemi KD, Aizebeokhai AP, Oladunjoye MA (2015) Integrated Geophysical and Geochemical Investigations of Saline Water Intrusion in a Coastal Alluvial Terrain, South-western Nigeria. Int. J. Appl Envir Sci ISSN 0973-6077 10, (4), pp. 1275-1288

Papazotos P, Koumantakis I, Vasileiou E (2019) Hydrogeochemical assessment and suitability of groundwater in a typical Mediterranean coastal area: A case study of the Marathon basin, NE Attica. Greece HydroResearch 2(2019):49-59

Piper AM (1953) A graphical procedure in the geochemical interpretation of water analysis.

Transactions, American Geophysical Union 25 914-923

Prasanna MV, Chidambaram S, Gireesh TV, Jabir Ali TV (2010) A study on Hydrochemical characteristics of Surface and Subsurface water in and around Perumal Lake, Cuddalore District, Tamilnadu. South India Environmental Earth Sciences (In Press). https://doi.org/10.1007/s12665-010-0664-6

Rajaveni SP, Brindha K, Elango L (2017) Geological and geomorphological controls on groundwater occurrence in a hard rock region. Appl Water Sci 7:1377-1389. https://doi.org/10.1007/ s13201-015-0327-6

Rao VVSG, Rao GT, Surinaidu L, Rajesh R, Mahesh J (2011) Geophysical and Geochemical Approach for Seawater Intrusion Assessment in the Godavari Delta Basin, A.P. India Water Air Soil Pollution 217:503-514

Ravindran AA, Ramanujam N, Sudarsan R (2013) Delineation of Saltwater and Freshwater Interphase in Beach Groundwater Study Using 2D ERI Technique in the Northern Sector of the Gulf of Mannar Coast, Tamilnadu. Water journal p 1-11

Russell IA and Impson ND (2006) Aquatic systems in and adjacent to Agulhas National Park with particular reference to the fish fauna. Koedoe 49(2): 45-57. Pretoria. ISSN 00756458

Sae-Ju J, Chotpantarat S, ThitimakornT, (2018) Assessment 1 of seawater intrusion using multivariate statistical, hydrochemical and geophysical techniques in coastal aquifer, Cha-am district, Thailand. Hydrol Earth Syst Sci Discuss. https://doi.org/10.5194/ hess-2018-137

Salman SA, Elnazer AA (2015) Evaluation of groundwater quality and its suitability fordrinking and agricultural uses in SW Qena Governorate. Egypt Adv in Nat Appl Sci 9(5):16-26

Satriani A, Loperte A, Imbrenda V, Lapenna V (2012) Geoelectrical surveys for characterization of the coastal saltwater intrusion in metapontum forest reserve (Southern Italy). Int J Geophys 2012. https://doi.org/10.1155/2012/238478

Song S, Lee G, Kim J, Seong B, Kim Y, Woo M, Park N (2006) Electrical Resistivity Survey for Delineating Seawater Intrusion in a Coastal Aquifer.pp.289-294

Supriyadi K, Putro AAP (2017) Geophysical and hydrochemical approach for seawater intrusion in North Semarang, Central Java. Indonesia Int J GEOMATE 12(31):134-140

Toens PD, Visser D, Van Der Westhuizen CR, Stadler W, Rasmussen JM (1998) Overberg Coastal Water Resources (Volume II): A Report to DWAF on the Groundwater Resources, Current and Future Water Requirements of the Coastal Strip and Adjoining Hinterland between the Potberg and Quoin Point, T and P, Toens and Partners, Cape Town, February

Wen Y, Qiu J, Cheng S (2020) Xu C and Gao X (2020) Hydrochemical Evolution Mechanisms of Shallow Groundwater and Its Quality 
Assessment in the Estuarine Coastal Zone: A Case Study of Qidong, China. Int J Environ Res Public Health 17:3382. https:// doi.org/10.3390/ijerph17103382

WHO (2011) Hardness in Drinking-water: Background document for development of WHO Guidelines for Drinking-water Quality, 11p

Xu Y, Lin L, Jia H (2009) Groundwater Flow Conceptualization and Storage Determination of the Table Mountain Group (TMG) Aquifers

Yusof NF, Mohamed Zawawi MA, Juahir H, Karim NZ (2016) Application of Geophysical Technique in Investigation of Groundwater Quality at Melaka Tengah, Malacca. J. Adv. Res Des 2462-1943 24 (1). Pages 1-12
Zaghlool E, Eissa M (2018) Integrated Geochemical Indicators and Geostatistics to Asses Processes Governing Groundwater Quality in Principal Aquifers, South Sinai. Egypt Middle East J Appl Sci 8(3):939-956

Weight WD (2008) Hydrogeology field manual, 2nd edn. McGraw-Hill Companies Inc, New York, USA

Publisher's Note Springer Nature remains neutral with regard to jurisdictional claims in published maps and institutional affiliations. 